\author{
UNIVERSIDADE DE SÃO PAULO \\ FACULDADE DE ODONTOLOGIA DE BAURU
}

ISABELA FURLANETO LEÃO

Anticariogenic potential and quantification of the enamel mineral elements around restorative materials

Potencial anticariogênico e quantificação dos elementos minerais do esmalte ao redor de materiais restauradores 



\section{Anticariogenic potential and quantification of the enamel mineral elements around restorative materials}

Potencial anticariogênico e quantificação dos elementos minerais do esmalte ao redor de materiais restauradores

Dissertação constituída por artigo apresentada a Faculdade de Odontologia de Bauru da Universidade de São Paulo para obtenção do título de Mestre em Ciências no Programa de Ciências Odontológicas Aplicadas, na área de concentração Dentística.

Orientadora: Profa. Dra ${ }^{a}$ Juliana Fraga Soares Bombonatti

Versão Corrigida 


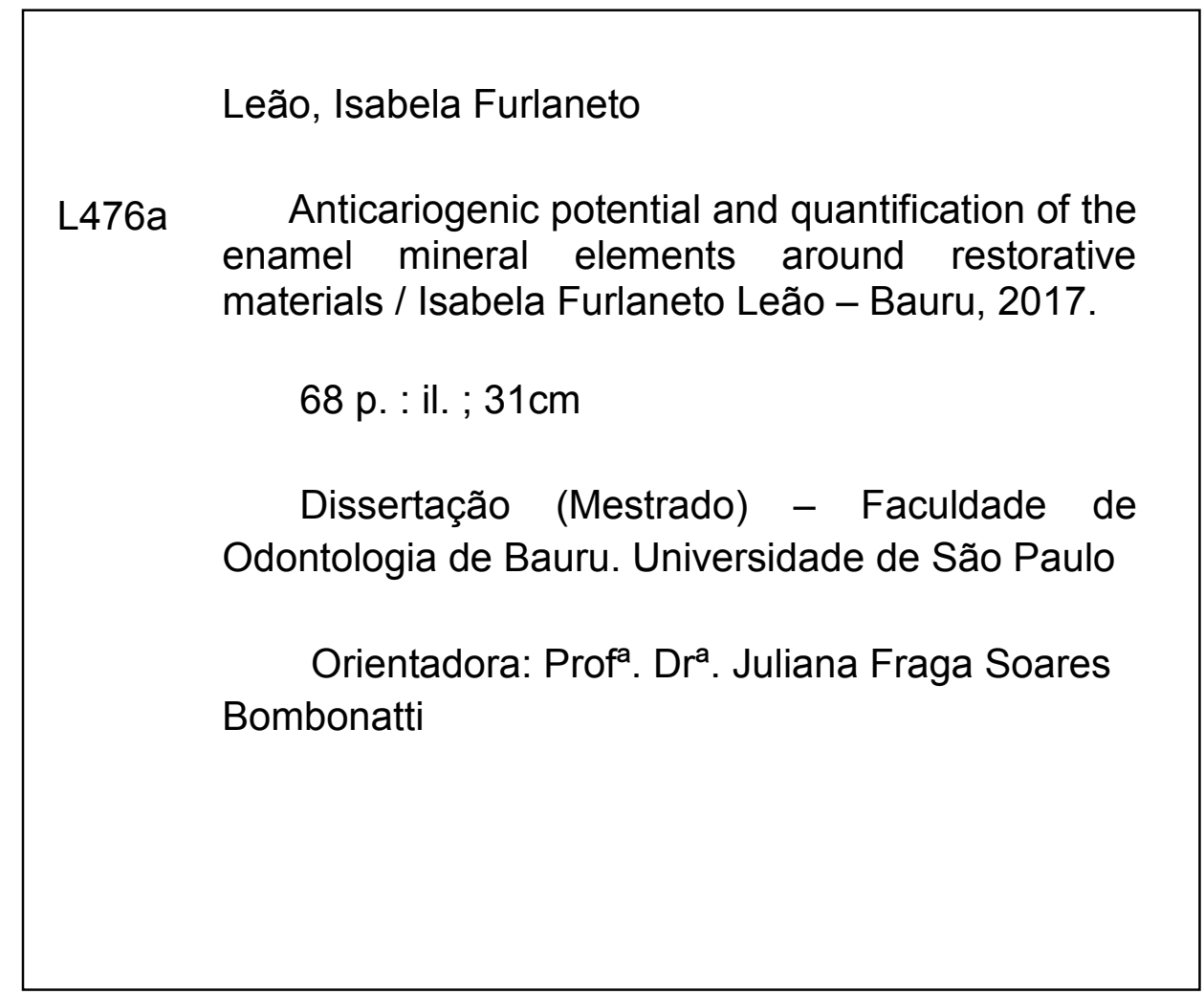

Nota: A versão original desta dissertação encontra-se disponível no Serviço de Biblioteca e Documentação da Faculdade de Odontologia de Bauru - FOB/USP.

Autorizo, exclusivamente para fins acadêmicos e científicos, a reprodução total ou parcial desta dissertação por processos fotocopiadores e outros meios eletrônicos.

Assinatura: 
FOLHA DE APROVAÇÃO 



\section{DEDICATÓRIA}

Em gratidão, dedico este trabalho à minha família, que sempre foi o alicerce da minha vida...

Aos mens amados pais, Paulo Roberto P. Leãoe Isabel

Cristina F. Leão, e aos mens irmãos Paulo Roberto P. Leão Fitho (Paulinho) e AndréfF. Leão, pelo amor incondicional e por estarem ao meu lado durante toda a minha vida. Ao mew amor, Fernando K. Rhoden, por fazer parte da minha vída de uma forma tão especial.

Ao final dessa caminhada tenho a certeza de que ao partir em busca dos mens sonhos, vocês sempre serão mens methores incentivadores. 



\section{AGRADECIMENTOS}

Primeiramente gostaria de agradecer a Dens que abençoou com toda sua graça todas as oportunidades da vida, sempre ituminando meu caminho e dando forças para ir em busca dos mens ideais, com equitíbrio na sua sabedoria e muita fé.

Aos mens amados pais, Paulo Roberto P. Leão e Isabel

Cristina F. Leão, que sempre acreditaram em mim e permitiram com que ew alcançasse mais este sonho. Vocês são os mens exemplos de vida... Obrigada pelo amor e carinho, pelas orações, dedicação e apoio durante toda a minha vida. Tudo o que sowé por vocês e em gratidão a vocês, ew os Amo muito fofinhos!

Ao men amado irmão Paulinho Leão, sempre tão cuidadoso e companheiro, sentirei saudades das nossas caroninhas até $\sigma$ apê. À minha querida cunhada-irmä Marina C. C. Leão, por todo companheirismo e parceria nos finais de semana, sempre ao mew lado tornando momentos cansativos da pesquisa, divertidose marcantes por toda minha vida. Obrigada por estarem sempre presente em minha vida, apoiando as minhas decisóes e torcendo com as minhas conquistas, vocês são feras.

Ao mew amado irmão caçulinha Andréf. Leão, pelo amore cumplicidade que nos une desde pequenos, por ser mew methor compantheiro, me proteger e vibrar a cada novo desafio. Somos exemplos de grandes amigos e a prova de que nada é maior que $\sigma$ carinho que sinto e o espaço que você ocupa em meu coração. 

Ao mew namorado Fernando $K$. Rhoden, por todo companheirismo, dedicação, amor e carinho que mesmo com essa enorme distância fez com momentos de saudade se tornassem forças para lutar por nossos sonhos e a cada surpresa e reencontro, com que eu me apaixonasse a cada dia mais. Vocêé minha inspiração de pessoa e profissionat. Que nesta nova fase, cada dia seja melhor que o outro eque aumente mais, nossas conquistas juntos. Obrigada por tudo mew A mor! Eute amo muito!

À minha familia gaícha Kleinubing Rhoden, em especial ao mens futuros sogros Roque Miguel Rhoden e Gema Iolanda K. Rhoden, por todo apoio e carinho. Vocês são muito especiais!

Em especial, à minha orientadora e amiga Prof. ${ }^{a}$ Dr. ${ }^{a}$ Juliana Fraga Soares Bombonatti, por ter me recebido tão bem desde o nosso primeiro contato e por ter acreditado em mim. Obrigada por todo apoio, confiança, ensinamentos e convivio compartithados ao longo desses anos, como aluna especiate mestranda. Agradeço por todas nossas conversas, sobre vida, família, trabalho, futuro a distancia e por todo carinho. É uma honra ser sua primeira orientada.

Ao Prof. Dr. Rafael Francisco Lia Mondelli, por ter me estendido a mão em todos os momentos que precisei, sempre pronto para ajudar e princípalmente, pela confiança e sabedoria transmitida. Você é o maior exemplo de profissional que ama e se dedica ar que faz. Serei sempre grata! 

Ao Prof. Dr. Tiago Donassolto, por sua disponibitidade desde minha ligação e aceite do convite, fico muito honrada de ter $\sigma$ futuro colega de profissão contribuindo com este trabalho.

Ao Prof. Dr. Carlos Nassar, muito obrigada pelo aceite do convite em participar da minha banca, por sua atençãoe contribuição com este trabalho.

À todos os professores do Departamento de Dentisticave Materiais Odontológicos FOB/USP:

Prof. Dr. José Mondelli, Prof. ${ }^{\text {D Dr. }}{ }^{a}$ María Teresa Atta, Prof. Dr. Adilson Yoshio Furuse, Prof. Dr. Sérgio Kiyoshi Ishikiriama, Prof. ${ }^{a}$ Dr. ${ }^{a}$ Ana Flávia Sanches Borges e Prof. Dr. Paulo Afonso Silveira Francisconi, que me receberam de braços abertose contribuiram para minha formação.

À Prof. ${ }^{a}$ Dr. ${ }^{a}$ Linda Wang, por ser um exemplo e sempre conseguir estimular os alunos a irem em busca de um novo aprendizado. Por nos inspirar a amar a profissão, se dedicar a cada dia e fazer a diferença. Agradeço por ter aprendido sempre um pouco mais com você, durante cada oportunidade ao longo da pós-graduação e poder levar essa essencia por toda minha carreira. Muito obrigada!

Ao querido professor da graduação e iniciação científica, Prof. Dr. Rodrigo Ricci Vivan, você foi minha primeira fonte de inspiração e meu primeiro impulso para este grande passo na vida acadêmica. Muito obrigada Digão! 

À minha querida turma de pós-graduação: Angélica, Fabricia, Fernanda, Giovanna, Lígia, Lorena, Mauro, Naiarae Natália, pelo convívio e experiências trocadas ao longo destes anos. Levarei um pouquinho de cada um de vocês, sucesso a todos.

De forma especial, agradeço à Naiara A. Oliveira, minha grande amiga e parceira ao longo dessa jornada, que permitiu com que os momentos dificeis se tornassem mais amenos. Na, obrigada por ter sido minha companheira durante todo $\sigma$ Mestrado, nos estágios, nas discíplinas, nos trabalhos reatizadose principalmente durante os experimentos da dissertação... Por dividir comigo, cada angustia, medo e divida durante essa fase, mas principalmente por todo o aprendizado que tivemos juntas. Sentirei saudades e lembrarei para sempre de todas as nossas conversas e risadas, do nosso convívio atém da FOB/USP, pelo carinho e principalmente pela sua amizade verdadeira e sincera para toda essa vida.

Ao querido amigo Bruno M. Guimarães (Tomate) que contribuiu muito para execução deste trabalho e sempre tão prestativo se fez presente e ajudow em cada etapa desta pesquisa.

À querida amiga Cassiana $K$. Scottu, por ser sempre tão prestativa e a cada ajuda aprendi um ensinamento que contribuiu para reatização deste trabalho. Meu sincero agradecimento e reconhecimento. No futuro nos encontraremos no sultchê! 

À querida amiga Marília M. A. C. Velo, por toda parcería, sempre combons consethos e experiencias a passar. Obrigada pela convivêncía durante estes anos, pelas inúmeras conversas, risadas e pela sua amizade que carrego além da vida acadêmica. Boa sorte nessa nova fase, torço muito por você!

À querida amiga Idiane Bianca L. S. Rusu, obrigada pela amizade e pelos bons momentos compartithados.

As minhas amigas da especiatização no Centrinho, por todo incentivo e torcida durante essa nova fase de desafiose conquistas.

Aos demais colegas da pós-graduação, pelo convívio e experiências trocadas durante este ciclo.

As queridas turmas da graduação, em especial a que pude acompanhar por mais tempo, a Turma LIV. Sinto-me honrada por acompanhar de perto $\sigma$ crescimento de vocês e participar de alguma forma dessa jornada, levarei em minhas lembranças nossa convivência nas aulas teóricas e os desafíos dos laboratóriog e clinicas de dentistica. Vocês são 10 !

Aos Funcionários de Departamento de Dentistica e Materiais Odontológicos e do Departamento de Bioquímica da FOB/USP, sempre prontos a ajudar:

Audria, Natália, Nelson, Charlene, Rita, Elisio, Lígia, Zuleica, Sandrinha, Alcides, Cleusa, Hebe, Thelma e Larissa. 

Ao Prof. José Roberto Pereira Lauris pela atençãoe orientação da análise estatistica.

Aos demais funcionários da Faculdade, que desempenharam suas funções com muita competência. 



\section{AGRADECIMENTOS INSTITUCIONAIS}

Ao CNPq, pelo apoio financeiro $e$ incentivo ao desenvolvimento da Ciencia através da bolsa de estudos durante a minha pós-graduação.

À Comissão de pós-graduação da Faculdade de Odontologia de Bauru, pela competêncía e eficiência.

Aos funcionários da Biblioteca e Documentação da FOB/USP que colaboraram com toda informação necessária para tornar possivel essa dissertação.

A Universidade de São Paulo pelas condições de estudo e pesquisa proporcionadas.

Ao Programa de Aperfeiçoamento em Ensino (PAE) por permitir o começo do exercício da docência.

Ao programa de pós-graduação em Odontologia, a Diretora eVice-diretor da Faculdade de Odontologia de Bauru, Prof. ${ }^{a}$ Dr. ${ }^{a}$ Maria Aparecida de Andrade e Prof. Dr. Carlos Ferreira dos Santos, pela coordenação da infraestrutura da FOB/USP.

E a todas as pessoas que de alguma forma colaboraram para que eu concluisse este trabatho.

Muito obrigada! 

"O futuro pertence àqueles que acreditam na beleza de seus sonhos." Elleanor Roosevelt 

ABSTRACT 



\section{ABSTRACT \\ Anticariogenic potential and quantification of the enamel mineral elements around restorative materials}

Objective: The aim of this in vitro study was to evaluate the anticariogenic potential and quantification of the enamel mineral elements around restorative materials after $\mathrm{pH}$-cycling, through the analysis of the microhardness of the enamel as well as the evaluation of $\mathrm{Ca} / \mathrm{P} / \mathrm{F}$ ratio by Energy-dispersive $\mathrm{X}$-ray spectroscopy analysis (EDS). Methods: Ninety blocks of bovine enamel after polishing were submitted to analysis of the microhardness and analysis of the composition in EDS, and sequentially randomly divided into six groups according to the treatment used ( $n=15$ ): F IX (Fuji IX Extra - GC Corporation); IZ (Ion Z - FGM); F II (Fuji II LC GC Corporation); B II (Beautifil II - Shofu); F250 (Filtek Z250 XT - 3M ESPE); and C (Control - No treatment). The specimens were subjected to $\mathrm{pH}$-cycling for 7 days. Subsequently, they were analyzed by EDS, and the final evaluations of the microhardness at standard distances from the treatment material. Results: The EDS findings revealed that there was a significant increase in Fluor concentration and decrease in Calcium in Group Bll after $\mathrm{pH}$-cycling. The values of the surface microhardness in $F I X, I Z$ and $F \|$ were higher than those in $B I I, F 250$ and $C$ at different distances of the materials. Conclusion: According to the methodology used, it can be concluded that restorative materials $\mathrm{F} \mathrm{IX,} \mathrm{IZ} \mathrm{and} \mathrm{F} \mathrm{II} \mathrm{were} \mathrm{able} \mathrm{to} \mathrm{partially}$ inhibit enamel demineralization under a dynamic $\mathrm{pH}$ cycling model. The giomer B II system demonstrated an intermediate anticariogenic potential and incorporation of fluoride in the enamel with statistical difference between Z250 and C, which did not show difference between them.

Key words: Dental enamel. Demineralization. Fluoride. Glass lonomer Cement. Composite Resin. 




\section{RESUMO}

Objetivo: $O$ objetivo deste estudo in vitro foi avaliar o potencial anticariogênico e quantificação dos elementos minerais do esmalte ao redor de materiais restauradores após ciclagem de $\mathrm{pH}$, através da análise da microdureza de superfície do esmalte e da avaliação do $\mathrm{Ca} / \mathrm{P} / \mathrm{F}$ por análise quantitativa em espectroscopia de energia dispersiva (EDS). Métodos: Noventa blocos de esmalte bovino após polimento foram submetidos a análise da microdureza superficial e análise da composição em EDS, e sequencialmente divididos aleatoriamente em seis grupos em função do tratamento empregado (n=15): F IX (Fuji IX Extra - GC Corporation); IZ (Ion Z - FGM); F II (Fuji II LC GC Corporation); B II (Beautifil II Shofu); F250 (Filtek Z250 XT - 3M ESPE) e C (Controle - Sem tratamento). Os espécimes foram submetidos à ciclagem de $\mathrm{pH}$ por sete dias. Posteriormente, a análise em EDS e microdureza de superfície final foi realizada em distâncias padronizadas em relação ao material de tratamento. Resultados: A análise em EDS demonstrou que houve aumento significativo na concentração de flúor e diminuição do cálcio para o grupo B II após ciclagem de pH. Os valores da microdureza de superfície do esmalte em F IX, IZ e F II foram maiores que os de B II, F250 e C nas diferentes distâncias dos materiais. Conclusão: De acordo com a metodologia utilizada, pode-se concluir que os materiais restauradores F IX, IZ e F II, foram capazes de inibir parcialmente a desmineralização do esmalte submetido a um modelo dinâmico de ciclagem de pH. O sistema giomer B II demonstrou um potencial anticariogênico intermediário e incorporação de flúor no esmalte com diferença estatística entre Z250 e C, os quais não apresentaram diferença entre si.

Palavras-chave: Esmalte dental. Desmineralização. Flúor. Cimento de ionômero de vidro. Resina composta. 



\section{LIST OF ILLUSTRATIONS}

Figure 1 - Schematic drawing of the experimental steps (1. Selection of teeth, section crowns and obtaining blocks; 2. Initial surface hardness and EDS; 3. Treatment of the specimens; 4. pH-cycling; 5. Final surface hardness and EDS)

Figure 2 - Schematic representation of the surface microhardness at standard distances

Figure 3 - Schematic representation of the specimen division Material area

Figure 4 - Schematic representation of the specimen division Control area 42

Figure 5 - Table showing the composition of the chemical solutions used for $\mathrm{pH}$-cycling

Figure 6 - Schematic representation of the surface microhardness at different areas of the specimen showing the standard distances to the material 44

Figure 7 - Graphical representation of initial and final surface hardness of the groups at different distances from restorative materials 



\section{LIST OF TABLES}

Table 1 - Materials evaluated 46

Table 2 - The means, standard deviation and comparison of the surface hardness of the experimental groups

Table 3 - The means, standard deviations and intragroup comparison (paired t tests) of each evaluated element $(\mathrm{Ca} / \mathrm{P} / \mathrm{F})$ at the initial condition and after $\mathrm{pH}$-cycling 48 



\section{TABLE OF CONTENTS}

1 INTRODUCTION

2 ARTICLE

3 DISCUSSION 51

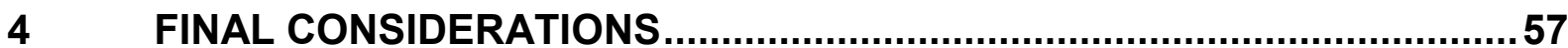

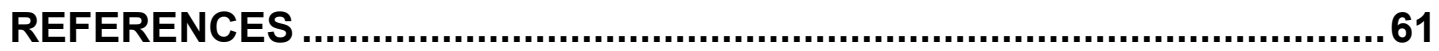

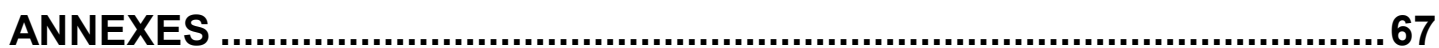



1 INTRODUCTION 



\section{INTRODUCTION}

Restorative Dentistry in the $\mathrm{XXI}$ century is based on the improvement of restorative materials, based on new technologies, prioritizing the association of aesthetics, function and integrity of dental structure with the challenges of the oral environment. Despite this evolution, the caries disease, multifactorial and diet / dependent, still represents a public health problem, since white spot lesions, the first clinical sign of the disease, appear with great frequency in the dental offices (COSTA et al., 2012; MARCENES et al., 2013, ZERO, 1999).

In this situation, promotion of oral health is a key to reduce population incidence of caries (WIEGAND et al., 2007, STECKSE N-BLICKS et al, 2007; BEHNAN et al, 2010). A considerable number of studies, aimed to understanding the development and progression of carious lesions, so research are conduct to know carious behavior and its relation with restorative materials (LIPPERT et al., 2015).

Fluoride releasing restorative materials have an anticariogenic potential, a fundamental property to reduce the risk of mineral loss, to control the recurrence of caries in the dental structure adjacent to the restoration and to contribute to a reduction in the incidence of caries. Thus, the attempt to develop restorative materials with the ability to release fluoride is a goal to control the evolution of the carious lesion (CURY et al., 2016; ASKAR et al., 2017).

The positive effect of fluoride in caries control disease was discovered in the early decades of the twentieth century, since then, this has been a great ally in Dentistry. The rational use of fluoride aims to make the most of their effect on caries control, with minimal adverse effects. The same will act by interfering with the demineralization and remineralization processes acting in post-irruptive mineralization, and inhibit bacterial metabolism (BUZALAF et al., 2013).

Glass ionomer cements (GICs) are widely used for their anticariogenic action and their ability to release and recharge fluoride, being capable to increase the fluoride ions available in oral environment (FORSTEN, 1995; GARCIA-CONTRERAS et al., 2015). It is known that a continued low concentration of fluoride ions in mouth could help reducing demineralization and enhancing remineralization (TEN CATE; FEATHERSTONE, 1991; CURY et al., 2016). 
Therefore, hybrid materials had been developed to combine the benefits of $\mathrm{GIC}$, to release and recharge fluoride, biocompatible and chemical adhesion and the esthetic of a resin composite (WIEGAND; BUCHALLA; ATTIN, 2007) with the addition of hidroxietil-methacrylate (HEMA) or bisfenolglicidilmethacrylate (BisGMA) in a resin modified glass ionomer cement (GARCIA-CONTRERAS et al., 2015). These materials had improved the mechanical properties of the $\mathrm{GIC}$, without interfering with its release of fluoride.

The class of resins composite materials was building up because its good clinical, due to its mechanical properties and aesthetics (FERRACANE, 2011). However, resins composite do not exhibit anticariogenic properties for the reason that it could not have the ability to release fluoride.

Consequently, in a search for developing new varieties of restorative materials, giomers was accomplished to match the release properties of fluoride and aesthetics of composite resins. (HOTWANI et al., 2013). The giomers are formed by acid / base reaction between glass particles (fluoride, boron, aluminum silicate filaments) and polyalkenoic acid in a prior presence of water before being inserted in the resin, designed a surface pre-reacted glass (S-PRG) filler (NAOUM et al., 2011).

Considering the importance of the described issue, there is a need to develop strategies for the control of cariogenic activity using fluoride materials.

Thus, the objective of this in vitro study was to evaluated the anticariogenic potential and quantification of the enamel mineral elements around restorative materials, testing the following null hypotheses:

I- There will be no difference in the anticariogenic potential of the restorative materials evaluated submitted to analysis of the microhardness;

II- There will be no difference in the quantification of the enamel mineral elements around restorative materials submitted analysis of the composition in EDS. 
2 ARTICLE 



\section{ARTICLE}

The article presented in this Dissertation was written according to the Operative Dentistry instructions and guidelines for article submission (Annex A). 


\section{ANTICARIOGENIC POTENTIAL AND QUANTIFICATION OF THE ENAMEL MINERAL ELEMENTS AROUND RESTORATIVE MATERIALS}

\section{ABSTRACT}

Objective: The aim of this in vitro study was to evaluate the anticariogenic potential and quantification of the enamel mineral elements around restorative materials after $\mathrm{pH}$-cycling, through the analysis of the microhardness of the enamel as well as the evaluation of $\mathrm{Ca} / \mathrm{P} / \mathrm{F}$ ratio by Energy-dispersive $\mathrm{X}$-ray spectroscopy analysis (EDS). Methods: Ninety blocks of bovine enamel after polishing were submitted to analysis of the microhardness and analysis of the composition in EDS, and sequentially randomly divided into six groups according to the treatment used (n=15): F IX (Fuji IX Extra - GC Corporation); IZ (Ion Z - FGM); F II (Fuji II LC GC Corporation); B II (Beautifil II - Shofu); F250 (Filtek Z250 XT - 3M ESPE); and C (Control - No treatment). The specimens were subjected to $\mathrm{pH}$-cycling for 7 days. Subsequently, they were analyzed by EDS, and the final evaluations of the microhardness at standard distances from the treatment material. Results: The EDS findings revealed that there was a significant increase in Fluor concentration and decrease in Calcium in Group Bll after pH-cycling. The values of the surface microhardness in F IX, IZ and F II were higher than those in B II, F250 and C at different distances of the materials. Conclusion: According to the methodology used, it can be concluded that restorative materials F IX, IZ and F II were able to partially inhibit enamel demineralization under a dynamic $\mathrm{pH}$ cycling model. The giomer B II system demonstrated an intermediate anticariogenic potential and incorporation of fluoride in the enamel with statistical difference between Z250 and C, which did not show difference between them.

KEYWORDS: Dental enamel. Demineralization. Fluoride. Glass Ionomer Cement. Composite Resin. 


\section{INTRODUCTION}

Restorative Dentistry in the 21st (XXI) century is based on the improvement of restorative materials, based on new technologies, prioritizing the association of aesthetics, function and integrity of dental structure with the challenges of the oral environment. Despite this evolution, the caries disease, multifactorial and diet / dependent, still represents a public health problem, since white spot lesions, the first clinical sign of the disease, appear with great frequency in the dental offices. .,2,3 $^{2}$

In this situation, promotion of oral health is a key to reduce population incidence of caries. ${ }^{4,5,6}$ A considerable number of studies, aimed to understanding the development and progression of carious lesions, so research are conduct to know carious behavior and its relation with restorative materials. ${ }^{7}$

Fluoride releasing restorative materials have an anticariogenic potential, a fundamental property to reduce the risk of mineral loss, to control the recurrence of caries in the dental structure adjacent to the restoration and to contribute to a reduction in the incidence of caries. Thus, the attempt to develop restorative materials with the ability to release fluoride is a goal to control the evolution of the carious lesion. ${ }^{8,9}$

The positive effect of fluoride in caries control disease was discovered in the early decades of the twentieth century, since then, this has been a great ally in Dentistry. The rational use of fluoride aims to make the most of their effect on caries control, with minimal adverse effects. The same will act by interfering with the demineralization and remineralization processes acting in post-irruptive mineralization, and inhibit bacterial metabolism. ${ }^{10}$

Glass ionomer cements (GICs) are widely used for their anticariogenic action and their ability to release and recharge fluoride, being capable to increase the fluoride ions available in oral environment. ${ }^{11,12}$ It is known that a continued low concentration of fluoride ions in mouth could help reducing demineralization and enhancing remineralization. ${ }^{13,8}$

Therefore, hybrid materials had been developed to combine the benefits of GIC, to release and recharge fluoride, biocompatible and chemical adhesion and the esthetic of a resin composite ${ }^{4}$ with the addition of hidroxietil-methacrylate (HEMA) or bisfenolglicidilmethacrylate (BisGMA) in a resin modified glass ionomer cement. ${ }^{12}$ 
These materials had improved the mechanical properties of the GIC, without interfering with its release of fluoride.

The class of resins composite materials was building up because its good clinical, due to its mechanical properties and aesthetics. ${ }^{14}$ However, resins composite do not exhibit anticariogenic properties for the reason that it could not have the ability to release fluoride.

Consequently, in a search for developing new varieties of restorative materials, giomers was accomplished to match the release properties of fluoride and aesthetics of composite resins. ${ }^{15}$ The giomers are formed by acid / base reaction between glass particles (fluoride, boron, aluminum silicate filaments) and polyalkenoic acid in a prior presence of water before being inserted in the resin, designed a surface pre-reacted glass (S-PRG) filler. ${ }^{16}$

Considering the importance of the described issue, there is a need to develop strategies for the control of cariogenic activity using fluoride releasing materials.

Thus, the objective of this in vitro study was to evaluated the anticariogenic potential and quantification of the enamel mineral elements around restorative materials, testing the following null hypotheses:

I- There will be no difference in the anticariogenic potential of the restorative materials evaluated submitted to analysis of the microhardness;

II- There will be no difference in the quantification of the enamel mineral elements around restorative materials submitted analysis of the composition in EDS.

\section{METHODS}

\section{Desing experimental}

An in vitro study was conducted to evaluate the anticariogenic potential and quantification of the enamel mineral elements around restorative materials (Table 1), with the variation factor restorative system on 6 levels F IX (Fuji IX Extra - GC Corporation), IZ (Ion Z - FGM), F II (Fuji II LC GC Corporation), B II (Beautifil II Shofu), F250 (Filtek Z250 XT - 3M ESPE) and C (Control - no treatment) through the 
analysis of the microhardness of enamel and quantitative analysis of the enamel composition by EDS (Fig. 1).

\section{Selection and preparation of enamel blocks}

Ninety blocks $(4 \times 4 \mathrm{~mm})$ were obtained from bovine incisors, which were selected after cleaning, removal of debris, and exclusion of units with cracks, fractures, hypocalcifications, and excessive wear of the incisal third.

The crowns were cut with a precision cutting machine (Isomet low-speed saw; Buehler, Lake Bluff, IL, USA) using two double-sided diamond disks (Extec Diamond Wafering blade; 5" x 0.015" x 1/2"; Extec Corp, Enfield, CT, USA). The cuts were processed at speed of 300 rpm under cooling with deionized water.

\section{Enamel polishing}

The dentin surface was planned to obtain specimens of $2 \mathrm{~mm}$ thickness, with the surface enamel and dentin parallel to each other.

After the blocks were repositioned and mounted on a metallographic polisher (Aropol 2V; Arotec, Cotia, SP, Brazil), they were polished using \# 600 and \# 1200 grit sandpaper discs (CarbiMet paper discs; Buehler, Lake Bluff, IL, USA) sequentially. The final polishing was performed using a felt disc with a $1-\mu \mathrm{m}$ diamond suspension (Buehler, Lake Bluff, IL, USA) at a high speed under a weight of $172 \mathrm{~g}$.

At each change of grit as well as at the end of the polishing process, the specimens were ultrasonicated in deionized water for 2 min using an ultrasonic device (USC 750; Unique Group, Indaiatuba, SP, Brazil) in order to remove any residue from polishing.

\section{$\mathrm{Ca} / \mathrm{P} / \mathrm{F}$ ratio by Energy-dispersive $\mathrm{X}$-ray spectroscopy analysis (EDS).}

A micro-analytical technique employed to estimate quantitatively the amount of mineral of the enamel using a Scanning Electron Microscope (Personal SEM [PSEM] eXpress; Aspex Corporation) equipped with an energy-dispersive spectrometer. Thus, Ca/P/F ratios were analysed for the groups before and after $\mathrm{pH}$-cycling. 


\section{Hardness measurements}

Surface hardness (Knoop) was determined using a microhardness tester (MicroMet 6040, Buehler, LAKE BLUFF, IL, USA) under a $25 \mathrm{~g}$ for $10 \mathrm{~s}$, coupled to an image analysis software (CAMS-WIN; NewAge Industries, Southampton, PA, USA).

The hardness values were calculated from the arithmetic mean of five indentations, $100 \mu \mathrm{m}$ apart, were made in the centre of enamel samples (Fig. 2). To establish the homogeneity of the samples, specimens with average surface hardness $>10 \%$ or $<10 \% 350 \mathrm{KHN}$ were excluded.

\section{Treatment of specimens}

After block randomization and sample homogeneity, ninety blocks ( $4 \times 4 \mathrm{~mm})$ was divided into two areas, each of $2 \mathrm{~mm}$ width and $2 \mathrm{~mm}$ length, measurements with digital caliper, delimiting the area where there will be a standardized cavity preparation (3mm by $1.5 \mathrm{~mm}$ ) with the diamond tip $\mathrm{N}^{\circ}$ 1093/1093F (Fig. 3). Sequentially, half the specimen was secured with tape for the treatment of enamel with the tested materials limiting the experimental area. The resins were inserted incrementally covered by polyester strip and pressed with a glass slide, to delimit the thickness of the material, by digital pressure and photopolymerized with photopolymerizer DB-685 (DABI ATLANTE, São Paulo, Brazil) light intensity of $961 \mathrm{~mW} / \mathrm{cm}^{2}$, both resins and Fuji II LC, was photoactivated for 20 seconds. The area designated as the cross-sectional hardness control was also covered with nitrocellulose lacquer base. Following treatment, the tape protecting was removed and the specimens were stored for $24 \mathrm{~h}$ in relative humidity at $37^{\circ} \mathrm{C}$. In the control group was not be realized cavity preparation and half of the specimen was covered with lacquer nitrocellulose base, protecting this region of $\mathrm{pH}$ cycling (Fig. 4).

\section{pH-cycling}

The specimens were subjected to a dynamic model of $\mathrm{pH}$-cycling for 7 days at $37^{\circ} \mathrm{C}$. During the first 5 days, the specimens were immersed in a demineralizing solution ( $\mathrm{pH} 4.7$ ) for $6 \mathrm{~h}$ followed by immersion in a remineralizing solution $(\mathrm{pH} 7.0)$ 
for $18 \mathrm{~h}$ (Fig. 5). On the final 2 days of the protocol, the specimens were immersed in the remineralizing solution. ${ }^{17}$

The specimens were immersed in the solutions separately. Each specimen was stored in a plastic container to avoid the sum effect of the fluoride ions released by the materials. In order to ensure total immersion of the specimens in the solutions, the volume of the solution in each container was maintained at $30 \mathrm{ml}$. Following $\mathrm{pH}-$ cycling, the specimens were stored at $37^{\circ} \mathrm{C} \pm 1^{\circ} \mathrm{C}$.

At each solution exchange, the specimens were washed under running deionized water, and the moisture was removed using blotting paper, before they were transferred to the next solution, which would have been stored in an incubator for $1 \mathrm{~h}$ prior to transfer.

\section{Analysis of the final surface hardness (SHf)}

Following the same method used in the analysis of the initial hardness (SHi) after $\mathrm{pH}$-cycling, the final surface hardness of each of the specimens was evaluated at standard distances of the indentations. The final hardness was performed with 5 indentations at standard distances of $150 \mu \mathrm{m}, 300 \mu \mathrm{m}$, and $450 \mu \mathrm{m}$ from the treatment area, with a separation of $100 \mu \mathrm{m}$ between each indentation (Fig. 6).

\section{Statistical Analysis}

The statistical analysis was determined by Statistc Program (SPSS - 17) and test of normality - Kolmogorov Smirnov.

\section{Surface hardness}

The effects of treatments on the final surface hardness were compared from a Variance analysis for repeated measures. The results indicated that the treatment was significant at the final hardness. To perform pairwise comparisons of treatment effects was made Tukey tests $(p<0.05)$. 


\section{Energy-dispersive X-ray analysis (EDS)}

For initial and final multiple comparisons within each group was used Paired ttests $(p<0.05)$ to evaluate the calcium level, phosphorus and fluoride.

\section{RESULTS}

\section{Surface hardness measurements}

The means and standart deviations of the surface hardness of the experimental groups are shown in Table 2.

Following pH-cycling, the treated groups, F IX, IZ and F II, showed the highest values of hardness at the three distances evaluated with a significant statistical difference in relation to the other groups, 150, 300 and $450 \mu \mathrm{m}(p<0.001)$, were able to maintain a surface hardness standard.

The giomer B II system demonstrated an intermediate behavior with a significant statistical difference between GICs and RM-GIC, Z250 and C (no treatment) with significantly higher hardness values than the Z250 composite resin and $C$ (no treatment) at the three distances evaluated.

The composite resin Z250 was the material that presented the lowest hardness results without significant statistical difference in relation to the $C$ (no treatment) in the 3 distances evaluated.

In the intragroup analysis (repeated measures analysis and Tukey tests) all the evaluated materials presented a decrease of the hardness values as the distance of the restoration increased.

\section{Energy-dispersive X-ray analysis (EDS)}

The means values and standard deviations of the evaluated elements at the initial condition and after $\mathrm{pH}$-cycling are shown in Table 3.

For initial and final multiple comparisons within each group, Paired t-tests was used, with a significance of ( $p$-value $<0.05)$. 
In the analysis of enamel elements minerals, B II showed a significant loss ( $p=$ $0.003)$ for calcium and a significant increase $(p=0.003)$ of fluoride in the enamel adjacent to the restoration.

For the evaluated materials and $C$ (no treatment) no significant alteration of the elements calcium, phosphorus and fluoride after $\mathrm{pH}$ cycling occurred.

\section{DISCUSSION}

The present study was conducted to determine the anticariogenic potential efficacy and quantify enamel mineral elements around commercial restorative materials - three glass ionomer cements, F IX (GIC), F II (RM-GIC) and IZ (GIC), a fluoride-releasing composite, B II (giomer), a composite resin, Z250 and C (no treatment). According to the results of this study, the null hypothesis that the materials tested could not inhibit enamel demineralization in dynamic cycling-pH challenge was rejected.

The glass ionomer cements (F IX, IZ and F II) were chosen for evaluation in this study, as their anticariogenic potential effectiveness, been reported by several studies. $^{9}$

The anticariogenic potential and the quantification of enamel elements $\mathrm{Ca} / \mathrm{P} / \mathrm{F}$ around restorative materials was estimated using in vitro models. Artificial enamel caries lesions are created to simulate the development of caries in vivo. ${ }^{17}$ The production of enamel caries lesions models in vitro is able to simulate the dynamics of loss and gain of minerals, allowing a better understanding of the interaction between demineralization and remineralization processes. ${ }^{18,19}$

Caries is a multifactorial, biofilm-dependent sugar disease. ${ }^{20}$ Thus, biofilm accumulation is the mean factor and sugar exposure is the negative determinant for caries progression on any intact or restored dental surface. The $\mathrm{pH}$ is the driving force that regulates the loss or gain of $\mathrm{Ca}$ and $\mathrm{P}$ from the mineral structure of the teeth. ${ }^{21,8}$

According to some studies, the enamel hardness is related to the mineral concentration in enamel, indicating a high correlation of the microhardness with 
microradiography analysis results, considered as a gold standard for the evaluation of mineral loss. $22,23,24,19$

Surface hardness analysis results, in the present study, showed that glass ionomer cements (GICs and RM-GIC) were able to partially inhibit enamel demineralization at a greater extent. Among them, there was evidence that Beautifil II showed an intermediate behavior between F IX, IZ, F II, Z250 and C (no treatment), with a significantly higher hardness values than $Z 250$ and $C$ (no treatment).

The mechanism in which glass ionomer cements release fluoride ions into an oral environment is proposed by two processes. Process I is a short-term reaction involving a fast dissolution of fluoride in the medium. The process II is more gradual and results in a diffusion of fluoride through the cement. ${ }^{25,26,4,27}$ In the present study, the release of $F I X, I Z$ and $F \|$ (GICs and RM-GIC) was probably due to an initial "burst" of fluoride release from the glass particles, which occurred when the fluoridecontaining glass powder reacted with polyalkanoic acid, so the enamel surface hardness averages were higher in comparison to B II and Z250.

Resin-modified glass ionomer cements (RM-GIC) were created to have a potential for fluoride release in amounts equivalent to conventional GICs. However, this potential is affected by several variables: the presence of fluoride compounds and their interaction with polyalkanoic acids, as well as the type and amount of resin used for the polymerization reaction. ${ }^{28,29,27}$

Among fluoride releasing materials, the distance of $150 \mu \mathrm{m}$ from the F II (RMGIC) showed the greatest hardness, but there was no statistical difference between GICs.

A possible explanation for these results is that when more distant the restorative material be, the surface hardness decreases, but $F$ IX, IZ and F II maintain a high hardness standard.

Giomers are presented in B II, a universal nanohybrid composite resin, composed by a surface pre - reacted glass (S-PRG) fillers. This S-PRG filler is formed by an acid/base reaction between glass particles (fluoride, boron, aluminum silicate filaments and polyalkanoic acid) in the presence of water, prior to being inserted into the resin and function as a filler in the resin matrix. Thus, B II differ from compomers, because the glass ionomer hydrogel inside compomers are formed after contact with water, that occur after polymerization. ${ }^{16}$ In addition to being an aesthetic 
material it is also indicated for restorations of cervical lesion, bonding of orthodontic brackets and patients who are at high risk for caries. The hardness results of B II and Z250 composite resins were statistically smaller compared to GICs and RM-GIC, and larger than $\mathrm{C}$ (no treatment). These results, could confirm hydroxyapatite dissolution and minerals loss in the medium in the absence of remineralizing agents.

The hardness loss demonstrated by $C$ (no treatment) was important for validation the $\mathrm{pH}$ cycling used in this study, ${ }^{17}$ demonstrated that bovine enamel demineralization had occurred, providing the proposed cariogenic challenge.

Some research gathered evidence to show the importance of fluoride mechanism and its topical effect to delay the progression of the lesion. ${ }^{30,21}$ Fluoride works at the point of acid attack to inhibit demineralization and stimulate remineralization. It inhibits the progression of bacterial metabolism and the progression of caries. ${ }^{31,10}$

Therefore, the inhibition of secondary caries associated with fluoride-releasing materials is attributed to a maintenance release of fluoride ions around restoration margins. $32,27,9$

Among the conditions of this study, the EDS analysis did have proved to be a sensitive and effective method to detect minor alterations of $\mathrm{Ca} / \mathrm{P} / \mathrm{F}$ mineral content as likewise occurred in the surface hardness evaluation.

However, the results of the EDS analysis after $\mathrm{pH}$ cycling showed that (GICs and RM-GIC) F IX, IZ and F II presented similar results, without statistical difference of calcium, phosphorus and fluoride ions percentages between the groups. This result was in agreement with previous findings. ${ }^{33,27}$

In contrast, B II suffered a significant loss for calcium and a significant increase of fluoride in the enamel adjacent to the restoration. For Z250 and C (no treatment) there was no significant change in calcium, phosphorus and fluoride after $\mathrm{pH}$ cycling.

Based on our findings, the glass ionomer-based materials evaluated could release fluoride at a sufficient doses that partially inhibit the formation of new lesions during the $\mathrm{pH}$ cycle. 


\section{CONCLUSIONS}

According to the methodology used and results analysis it could be concluded that:

I - The fluoride releasing restorative materials tested were able to partially inhibit enamel demineralization when subjected to a dynamic $\mathrm{pH}$ cycling model, with the best behavior of the glass ionomer cement, followed by giomer. The composite resin did not present an anticariogenic potential.

II - Quantifying enamel mineral elements around restorative materials, the giomer Beautifil II presented calcium ions loss and a greater incorporation of fluoride ions in enamel.

\section{REFERENCES}

1. Costa SM, Martins CC, Bonfim Mde L, Zina LG, Paiva SM, Pordeus IA \& Abreu $\mathrm{MH}$ (2012) A systematic review of socioeconomic indicators and dental caries in adults International Journal Environ Research Public Health 9(10) 3540-3574.

2. Marcenes W, Kassebaum NJ, Bernabé E, Flaxman A, Naghavi M, Lopez A \& Murray CJ (2013) Global burden of oral conditions in 1990-2010: a systematic analysis Journal Dentistry Research 92(7) 592-597.

3. Zero DT (1999) Dental caries process Dental Clin North American 43(4) 635-664.

4. Wiegand A, Buchalla W \& Attin T (2007) Review on fluoride-releasing restorative materials - Fluoride release and uptake characteristics, antibacterial activity and influence on caries formation Dental Materials Journal 23(3) 343-362.

5. Stecksén-Blicks C, Renfors G, Oscarson ND, Bergstrand F \& Twetman S (2007) Caries-preventive effectiveness of a fluoride varnish: a randomized controlled trial in adolescents with fixed orthodontic appliances Caries Research 41(6) 455459.

6. Behnan SM, Arruda AO, González-Cabezas C \& Sohn W (2010) In-vitro evaluation of various treatments to prevent demineralization next to orthodontic brackets American Journal Orthodontics Dentofacial Orthophedic 13(8) 712-721. 
7. Lippert F \& Juthani K (2015) Fluoride dose response of human and bovine enamel artificial caries lesions under $\mathrm{pH}$-cycling conditions Clinical Oral Investigation 19(8) 1947-1954.

8. Cury JA, de Oliveira BH, Dos Santos AP \& Tenuta LM (2016) Are fluoride releasing dental materials clinically effective on caries control? Dental Materials Journal 32(3) 323-333.

9. Askar H, Tu YK, Paris S, Yeh YC \& Schwendicke F (2017) Risk of caries adjacent to different restoration materials: Systematic review of in situ studies Journal of Dentistry 56 1-10.

10. Buzalaf, MAR (2013) Mecanismo de ação de fluoreto no controle da cárie dentária Fluoretos e Saúde Bucal Editora Santos Cap (8) 201-225.

11. Forsten $L$ (1995) Resin-modified glass ionomer cements: Fluoride release and uptake Acta Odontologica Scandinavica 53(4) 225-235.

12. Garcia-Contreras R, Scougall-Vilchis RJ, Contreras-Bulnes R, Sakagami H, Morales-Luckie RA \& Nakajima H (2015) Mechanical, antibacterial and bond strength properties of nano-titanium enrinched glass ionomer cement Journal of Applied Oral Science 23(3) 321-328.

13. ten Cate JM \& Featherstone JD (1991) Mechanistic aspects of the interactions between fluoride and dental enamel Crit Rev Oral Biol Med 2(3) 283-296.

14. Ferracane JL (2011) Resin composite - state of the art Dental Materials Journal 27(1) 29-38.

15. Hotwani K, Thosar K, Baliga S, Bundale S \& Sharma K (2013) Antibacterial effects of hybrid tooth colored restorative materials against Streptococcus mutans: An in vitro analysis Journal of Conservative Dentistry 16(4) 319-322.

16. Naoum S, Ellakwa A, Martin F \& Swain M (2011) Fluoride release, recharge and mechanical property stability of various fluoride - Containing Resin Composite Operative Dentistry 36(4) 422-432.

17. Vieira AE, Delbem AC, Sassaki KT, Rodrigues E, Cury JA \& Cunha RF (2005) Fluoride dose response in pH-cycling models using bovine enamel Caries Research 39(6) 514-520.

18. White DJ (1995) The application of in vitro models to research on demineralization and remineralization of the teeth Adv Dent Research 9(3) 175193.

19. Magalhães AC, Moron BM, Comar LP, Wiegand A, Buchalla W \& Buzalaf MA (2009) Comparison of cross-sectional hardness and transverse microradiography 
of artificial carious enamel lesions induced by different demineralising solutions and gels Caries Reserch 43(6) 474-483.

20. Cury JA \& Tenuta LMA (2009) Enamel remineralization: controlling the caries disease or treating early caries lesions? Brazilian Oral Research 23(1) 23-30.

21. Fejerskov $\mathrm{O}$ (2004) Changing paradigms in concepts on dental caries: consequences for oral health care. Caries Research 38(3) 182-191.

22. Arends J, Schuthof J \& Jongebloed WG (1979) Microhardness indentations on artificial white spot lesions Caries Research 13(5) 290-297.

23. Featherstone JDB, ten Cate JM, Shariati M \& Arends J (1983) Comparison of artificial caries-like lesions by quantitative microradiography and microhardness profiles Caries Research 17(5) 385-391.

24. Kielbassa AM, Wrbas KT, Schulte-Mönting J \& Hellwig E (1999) Correlation of transversal microradiography and microhardness on in situ-induced demineralization in irradiated and non irradiated human dental enamel Archives of Oral Biology 44(3) 243-251.

25. Dhondt CL, De Maeyer EA \& Verbeeck RM (2001) Fluoride release from glass ionomer activated with fluoride solutions Journal Dentistry Research 80(5) 14021406.

26. Williams JA, Billington RW \& Pearson GJ (2001) A long-term study of fluoride release from metal-containing conventional and resin-modified glass-ionomer cements Journal Oral Rehability 28(1) 41-47.

27. Dionysopoulos $P$, Koliniotou-Koumpia E, Helvatzoglou-Antoniades M \& Kotsanos $N$ (2013) Fluoride release and recharge abilities of contemporary fluoridecontaining restorative materials and dental adhesives Dental Materials Journal 32(2) 296-304.

28. Tjandrawinata R, Irie M \& Suzuki K (2004) Marginal gap formation and fluoride release of resin-modified glass-ionomer cement: effect of silanized spherical silica filler addition Dental Materials Journal 23(3) 305-313.

29. DeSchepper EJ, Berr EA, Cailletean JG \& Tate WH (1991) A comparative study of fluoride release from glass ionomer cements Quintessence International 22(3) 215-219.

30. Fejerskov O, Thylstrup A \& Larson MJ (1981) Rational use of fluorides in caries prevention. A concept based on possible cariostatic mechanisms Acta Odontologica Scandinavica 39(4) 241-249. 
31. Kidd $E$ (2011) The implications of the new paradigm of dental caries Journal of Dentistry 39(2) 3-8.

32. Dijkman GE \& Arends J (1992) Secondary caries in situ around fluoride-releasing light-curing composites: a quantitative model investigation on four materials with fluoride content between 0 and 26 vol\% Caries Research 26(5) 351-357.

33. Yap AU, Tham SY, Zhu LY \& Lee HK (2002) Short-term fluoride release from various aesthetic restorative materials Operative Dentistry 27(3) 259-265. 


\section{FIGURE CAPTIONS}

Fig 1. Schematic drawing of the experimental steps (1. Selection of teeth, section crowns and obtaining blocks; 2 . Initial surface hardness and EDS; 3 . Treatment of the specimens; 4. pH-cycling; 5. Final surface hardness and EDS)

Fig 2. Schematic representation of the surface microhardness at standard distances

Fig 3. Schematic representation of the specimen division - Material area.

Fig 4. Schematic representation of the specimen division - Control area.

Fig 5. Table showing the composition of the chemical solutions used for $\mathrm{pH}$-cycling

Fig 6. Schematic representation of the surface microhardness at different areas of the specimen showing the standard distances to the material.

Fig 7. Graphical representation of initial and final surface hardness of the groups at different distances from restorative materials 


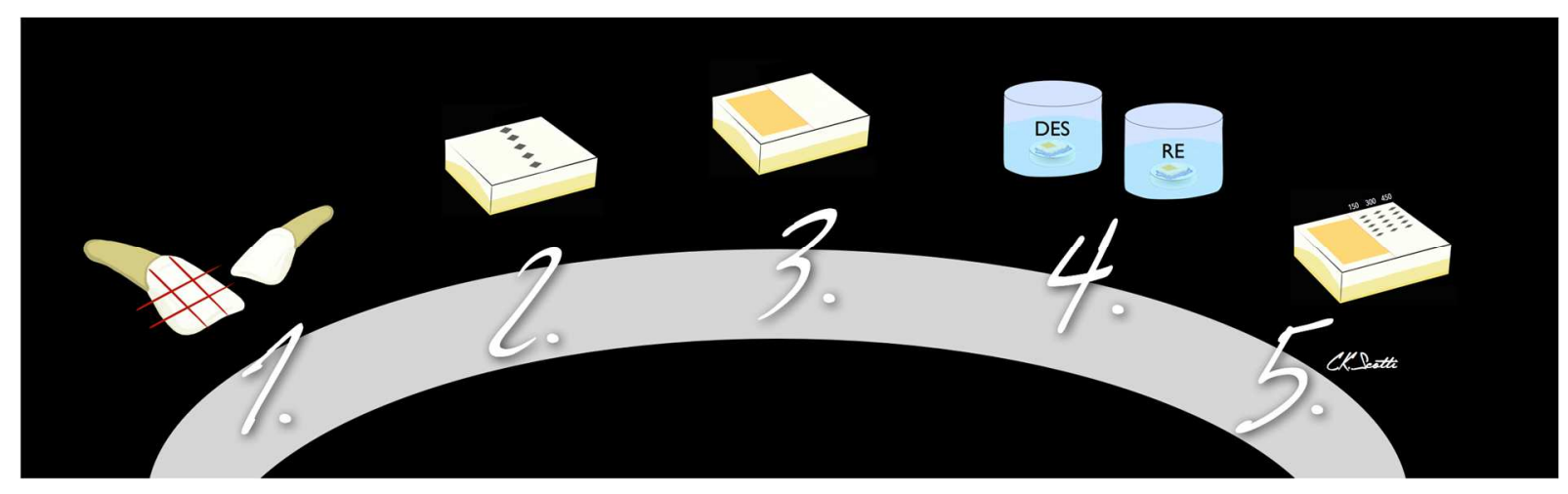

Fig 1 


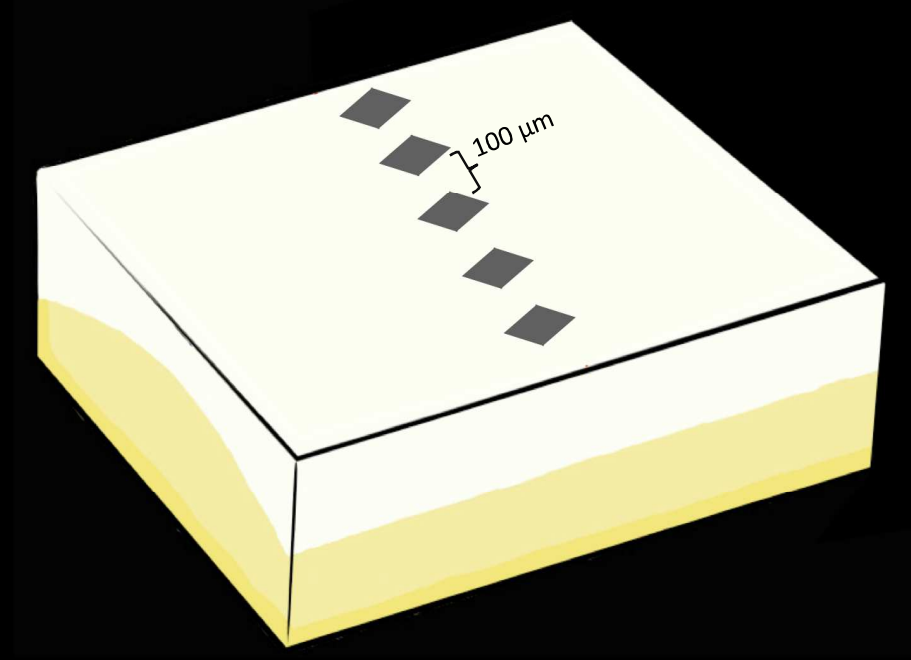

Fig 2 


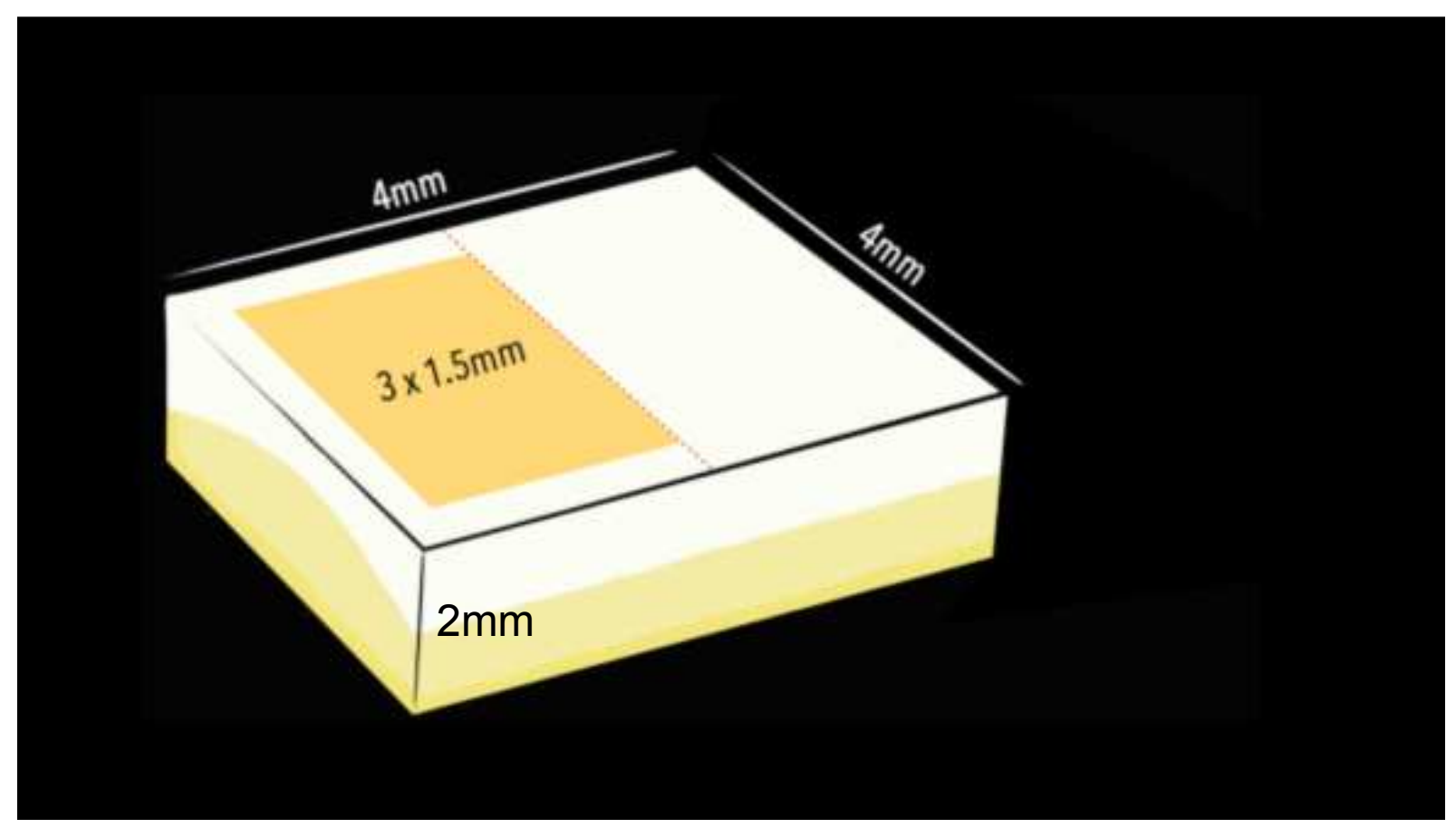

Fig 3 


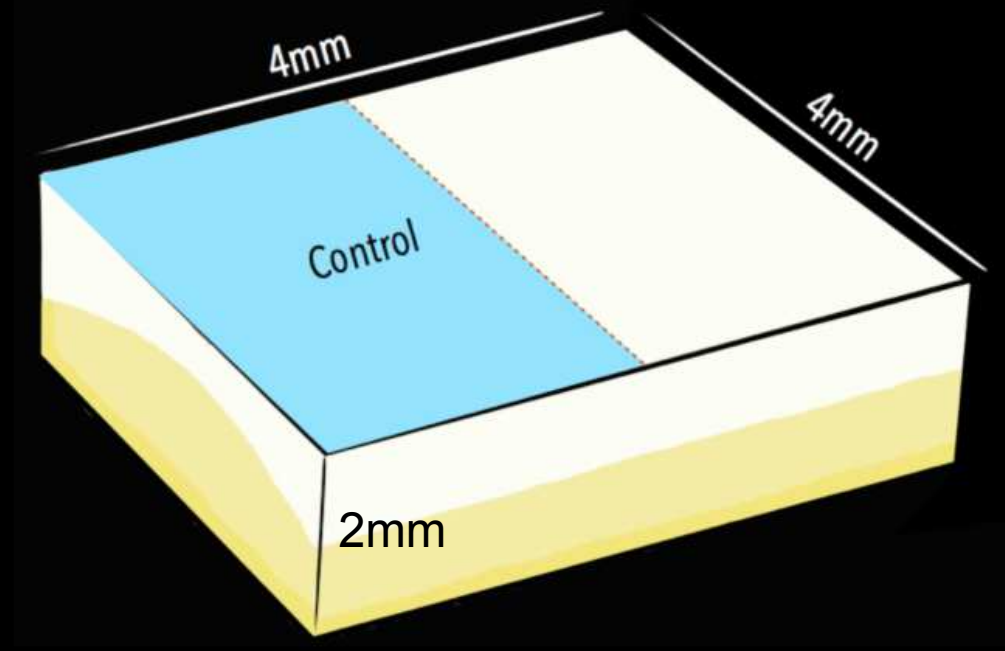

Fig 4 


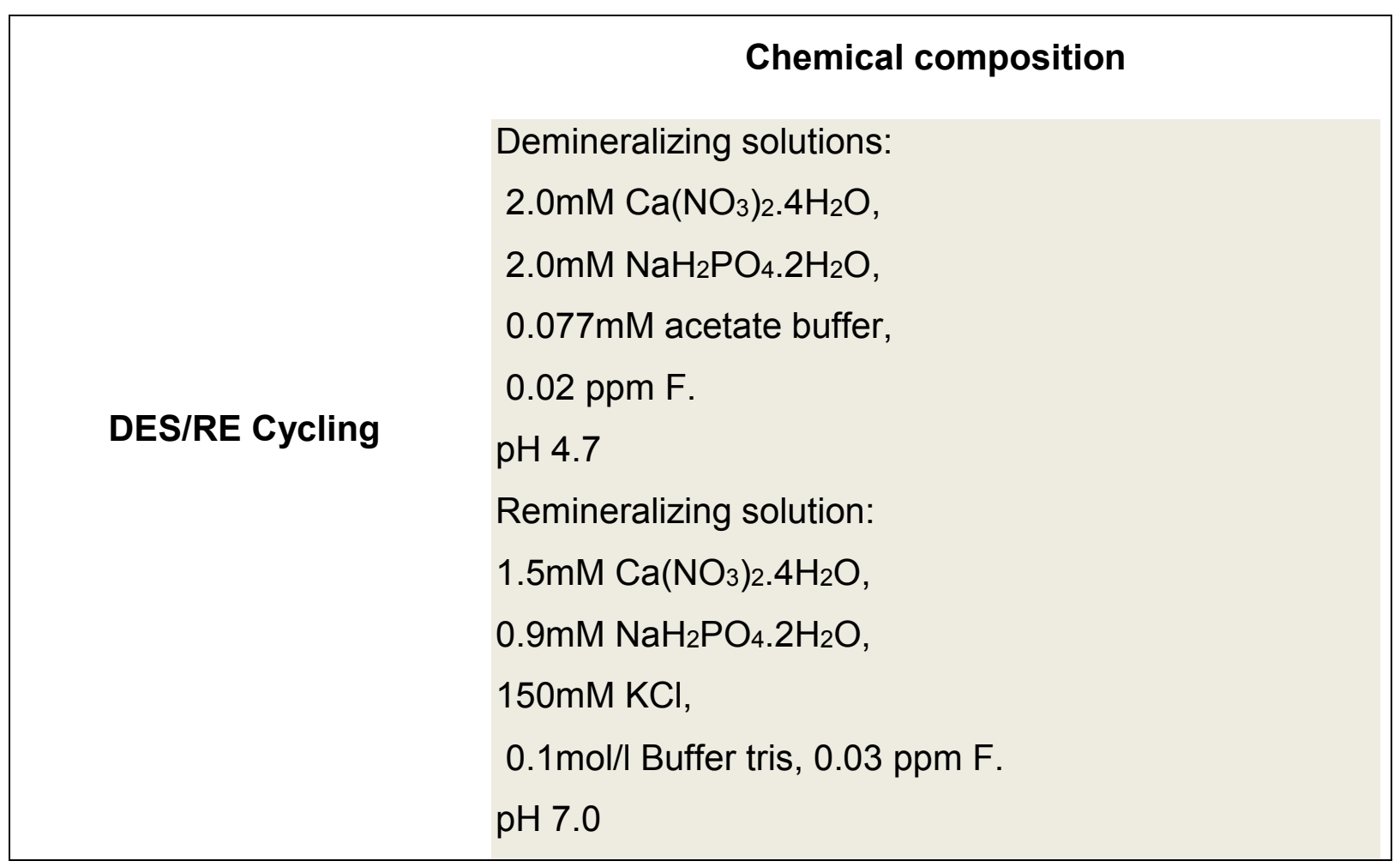

(Vieira et al., 2005)

Fig 5 


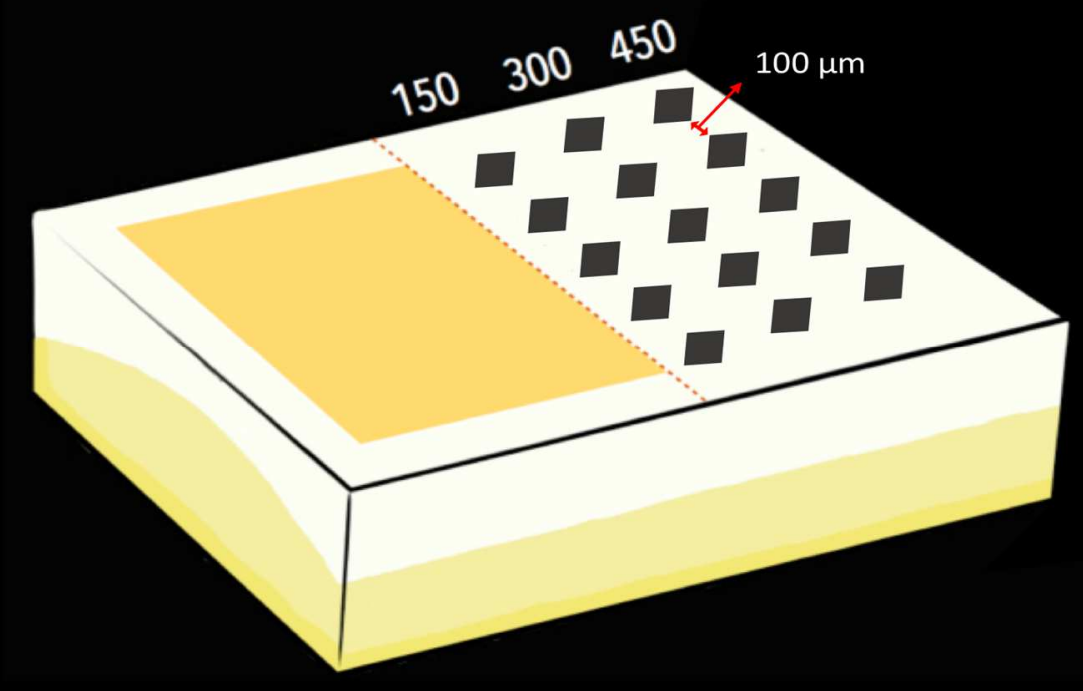

Fig 6 


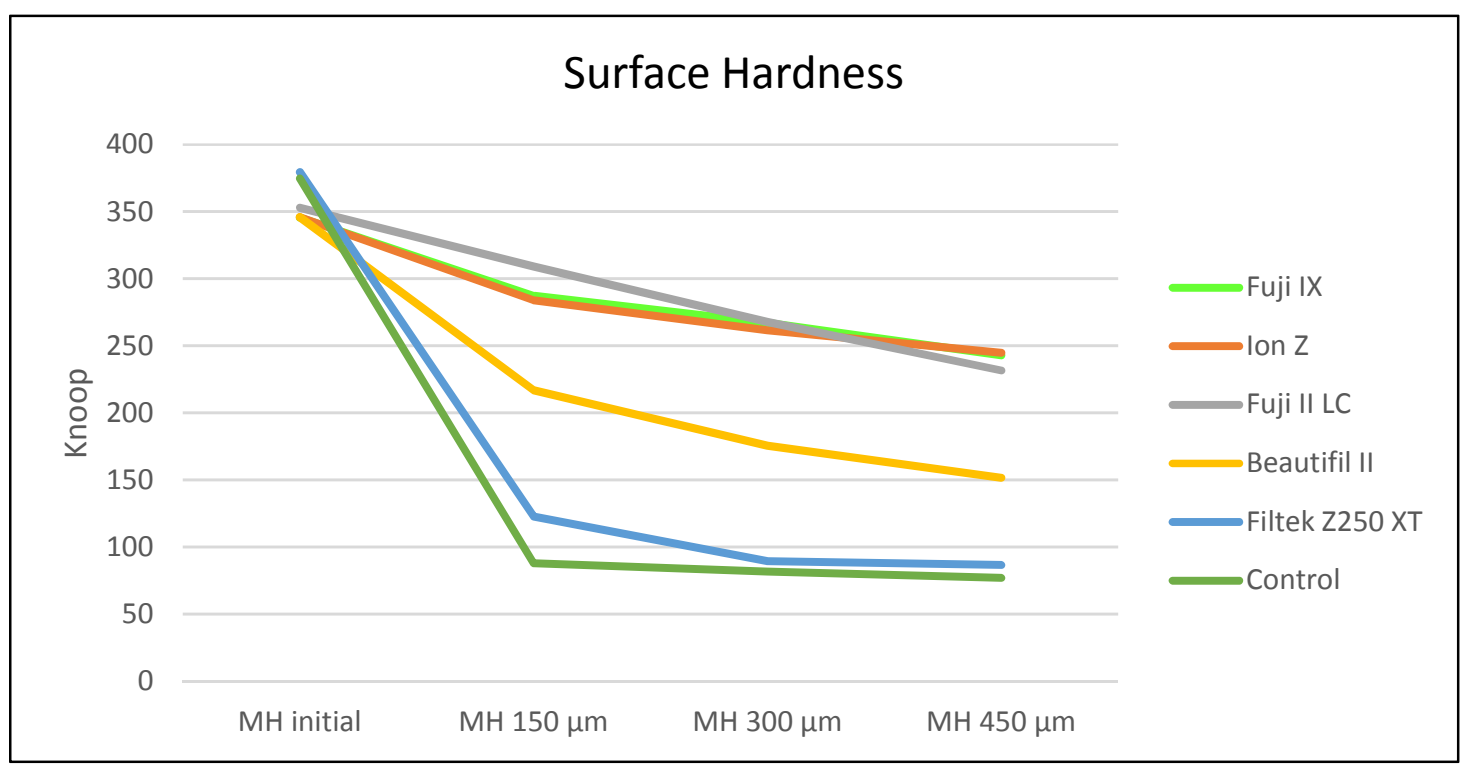

Fig 7 
Table I. Materials evaluated:

\begin{tabular}{|c|c|c|}
\hline Materials & Classification & Composition \\
\hline $\begin{array}{l}\text { Beautifil II } \\
\text { (Shofu) }\end{array}$ & $\begin{array}{c}\text { Composite resin - fluoride- } \\
\text { containing resin composite } \\
\text { (Giomer system) }\end{array}$ & $\begin{array}{lc}\text { Glass particle S-PRG } & \text {, glass } \\
\text { fluoride - } & \text { aluminum } \\
\text { borosilicate } & \text { particles, } \\
\text { TEGDMA }^{b}, & \text { Bis-GMA } \\
\text { particles' size } & 20-40 \mathrm{~nm} .\end{array}$ \\
\hline $\begin{array}{l}\text { Filtek Z250 } \\
\text { (3M ESPE) }\end{array}$ & $\begin{array}{l}\text { Composite resin } \\
\text { (Negative control) }\end{array}$ & $\begin{array}{ll}\text { BisGMA, UDMAd, } & \text { BisEMA }^{e} \\
\text { (zirconia/silica), } & \text { particles' } \\
\text { size } 0,01-3,5 \mu \mathrm{m} . & \end{array}$ \\
\hline $\begin{array}{l}\text { Fuji IX Extra } \\
\text { (Shofu) }\end{array}$ & $\begin{array}{c}\text { Conventional Glass lonomer } \\
\text { Cement } \\
\text { (Positive control) }\end{array}$ & $\begin{array}{l}\text { Fluoride - aluminum - silicate } \\
\text { glass, potassium } \\
\begin{array}{l}\text { persulphate and ascorbic } \\
\text { acid. }\end{array}\end{array}$ \\
\hline $\begin{array}{l}\text { Fuji II LC } \\
\text { (Shofu) }\end{array}$ & $\begin{array}{l}\text { Modified glass ionomer cement } \\
\text { (Positive control) }\end{array}$ & $\begin{array}{l}\text { Fluoride - aluminum - silicate } \\
\text { calcium glass particles, } \\
\text { composite monomers and } \\
\text { photo initiators. }\end{array}$ \\
\hline $\begin{array}{l}\text { Ion Z } \\
\text { (FGM) }\end{array}$ & $\begin{array}{c}\text { Conventional Glass lonomer } \\
\text { Cement } \\
\text { (Positive control) }\end{array}$ & $\begin{array}{l}\text { Glass of calcium-aluminum- } \\
\text { zinc-fluoride- } \\
\text { silicate,polycarboxilic acid, } \\
\text { deionized water, titanium } \\
\text { dioxide, iron oxide. }\end{array}$ \\
\hline
\end{tabular}

a S-PRG: surface pré-reacted glass;

bTEGDMA: triethyleneglycoldimethacrylate.

'BisGMA: 2,2-Bis[4-(2-hydroxy-3-methacryloxypropyl-1-oxyphenylpropane

dUDMA: urethanedimethacrylate;

eBISEMA: 2,2-Bis[4-(2-methacryloxyethoxy) phenylpropane. 
Table II. The means, standard deviation and comparison of the surface hardness of the experimental groups.

\begin{tabular}{|c|c|c|c|c|}
\hline Group & MH initial & $\begin{array}{c}\text { MH } \\
\text { final } 150\end{array}$ & $\begin{array}{c}\text { MH } \\
\text { final } 300\end{array}$ & $\begin{array}{c}\text { MH } \\
\text { final } 450\end{array}$ \\
\hline $\begin{array}{c}\text { F IX } \\
\text { Fuji IX }\end{array}$ & $\begin{array}{c}345.53 \mathrm{Aa} \\
\pm 36.74\end{array}$ & $\begin{array}{c}287.40 \mathrm{Ba} \\
\pm 57.78\end{array}$ & $\begin{array}{c}267.07 \mathrm{BCa} \\
\pm 58.29\end{array}$ & $\begin{array}{c}242.93 \mathrm{Ca} \\
\pm 63.32\end{array}$ \\
\hline $\begin{array}{c}\text { I Z } \\
\text { Ion Z }\end{array}$ & $\begin{array}{c}346.00 \mathrm{Aa} \\
\pm 35.59\end{array}$ & $\begin{array}{l}284.00 \mathrm{Ba} \\
\pm 39.08\end{array}$ & $\begin{array}{c}261.53 \mathrm{BCa} \\
\pm 47.93\end{array}$ & $\begin{array}{c}244.80 \mathrm{Ca} \\
\pm 46,22\end{array}$ \\
\hline $\begin{array}{c}\text { F II } \\
\text { Fuji II LC }\end{array}$ & $\begin{array}{c}352.93 \mathrm{Aa} \\
\pm 31.04\end{array}$ & $\begin{array}{c}309.13 \mathrm{Ba} \\
+29.67\end{array}$ & $\begin{array}{c}267.80 \mathrm{Ca} \\
\pm 23.02\end{array}$ & $\begin{array}{c}231.73 \mathrm{Da} \\
\pm 35.85\end{array}$ \\
\hline $\begin{array}{c}\text { B II } \\
\text { Beautifil II }\end{array}$ & $\begin{array}{c}345.93 \mathrm{Aa} \\
\pm 33.70\end{array}$ & $\begin{array}{c}216.87 \mathrm{Bb} \\
+45.63\end{array}$ & $\begin{array}{c}175.67 \mathrm{Cb} \\
\pm 31.41\end{array}$ & $\begin{array}{c}151.73 \mathrm{Cb} \\
\pm 32.32\end{array}$ \\
\hline $\begin{array}{c}\text { F } 250 \\
\text { Filtek Z250 } \\
\text { XT }\end{array}$ & $\begin{array}{c}379.60 \mathrm{Aa} \\
+24.55\end{array}$ & $\begin{array}{c}122.67 \mathrm{Bc} \\
\pm 22.21\end{array}$ & $\begin{array}{c}89.67 \mathrm{Cc} \\
\pm 11.69\end{array}$ & $\begin{array}{c}86.67 \text { Cc } \\
\pm 20.28\end{array}$ \\
\hline $\begin{array}{c}\text { C } \\
\text { Control }\end{array}$ & $\begin{array}{c}374.80 \mathrm{Aa} \\
+32.23\end{array}$ & $\begin{array}{c}88.13 \mathrm{Bc} \\
+6.48\end{array}$ & $\begin{array}{c}81.80 \mathrm{Bc} \\
+6.28\end{array}$ & $\begin{array}{c}77.07 \mathrm{Bc} \\
+9.31\end{array}$ \\
\hline \multicolumn{5}{|c|}{$\begin{array}{l}\text { - Different capital letters in same row mean statistically significant differences } \\
\text { ( } p<0.05) \text { - Repeated Measures Analysis of Variance and Tukey tests } \\
\text { - Different small letters in same column mean statistically significant differences } \\
\text { ( } p<0.05) \text { - Analysis of Variance and Tukey tests } \\
\text { - Surface hardness measurements Knoop } 350 \mathrm{KHN}\end{array}$} \\
\hline
\end{tabular}


Table III. The means, standard deviations and intragroup comparison (paired t tests) of each evaluated element in percentage $(\mathrm{Ca} / \mathrm{P} / \mathrm{F})$ at the initial condition and after $\mathrm{pH}$-cycling

\begin{tabular}{|c|c|c|c|c|c|c|}
\hline Group & $\begin{array}{c}\mathrm{Ca} \\
\text { initial }\end{array}$ & $\begin{array}{c}\text { Ca } \\
\text { final }\end{array}$ & $\begin{array}{c}\mathbf{P} \\
\text { initial }\end{array}$ & $\begin{array}{c}P \\
\text { final }\end{array}$ & $\begin{array}{c}\mathbf{F} \\
\text { initial }\end{array}$ & $\begin{array}{c}F \\
\text { final }\end{array}$ \\
\hline $\begin{array}{c}\text { F IX } \\
\text { Fuji IX }\end{array}$ & $\begin{array}{r}54.05 \\
+0.95\end{array}$ & $\begin{array}{r}53.60 \\
\pm 0.83\end{array}$ & $\begin{array}{l}37.09 \\
\pm 0.21\end{array}$ & $\begin{array}{l}37.16 \\
+0.15\end{array}$ & $\begin{array}{r}1.55 \\
+0.15\end{array}$ & $\begin{array}{r}1.60 \\
+0.15\end{array}$ \\
\hline $\begin{array}{l}\text { I Z } \\
\text { Ion Z }\end{array}$ & $\begin{array}{r}53.80 \\
+0.95\end{array}$ & $\begin{array}{r}53.89 \\
+0.93\end{array}$ & $\begin{array}{l}37.12 \\
+0.13\end{array}$ & $\begin{array}{l}37.20 \\
+0.26\end{array}$ & $\begin{array}{r}1.58 \\
+0.17\end{array}$ & $\begin{array}{r}1.55 \\
+0.14\end{array}$ \\
\hline $\begin{array}{c}\text { F II } \\
\text { Fuji II LC }\end{array}$ & $\begin{array}{r}54.01 \\
+0.77\end{array}$ & $\begin{array}{l}53.29 \\
\pm 1.04\end{array}$ & $\begin{array}{l}37.11 \\
+0.15\end{array}$ & $\begin{array}{r}37.2 \\
+0.32\end{array}$ & $\begin{array}{r}1.52 \\
+0.13\end{array}$ & $\begin{array}{r}1.62 \\
+0.14\end{array}$ \\
\hline $\begin{array}{c}\text { B II } \\
\text { Beautifil II }\end{array}$ & $\begin{array}{l}54.05^{*} \\
+0.69\end{array}$ & $\begin{array}{l}53.13^{*} \\
+0.75\end{array}$ & $\begin{array}{l}37.16 \\
+0.19\end{array}$ & $\begin{array}{l}37.11 \\
+0.27\end{array}$ & $\begin{array}{l}1.51^{*} \\
+0.10\end{array}$ & $\begin{array}{l}1.67^{*} \\
+0.12\end{array}$ \\
\hline $\begin{array}{c}\text { F } 250 \\
\text { Filtek Z250 } \\
\text { XT }\end{array}$ & $\begin{array}{r}53.65 \\
+0.92\end{array}$ & $\begin{array}{r}52.89 \\
+1.52\end{array}$ & $\begin{array}{l}37.35 \\
+0.17\end{array}$ & $\begin{array}{l}37.39 \\
+0.34\end{array}$ & $\begin{array}{r}1.52 \\
+0.15\end{array}$ & $\begin{array}{r}1.54 \\
+0.16\end{array}$ \\
\hline $\begin{array}{c}\text { C } \\
\text { Control }\end{array}$ & $\begin{array}{l}53.69 \\
+1.02\end{array}$ & $\begin{array}{l}53.82 \\
\pm 1.51\end{array}$ & $\begin{array}{l}37.37 \\
+0.25\end{array}$ & $\begin{array}{l}37.41 \\
+0.26\end{array}$ & $\begin{array}{r}1.55 \\
+0.15\end{array}$ & $\begin{array}{r}1.52 \\
+0.24\end{array}$ \\
\hline
\end{tabular}

Statistically significant $(P<0.05)$ 
3 DiscussiON 



\section{DISCUSSION}

The present study was conducted to determine the anticariogenic potential efficacy and quantify enamel mineral elements around commercial restorative materials - three glass ionomer cements, FIX (GIC), F II (RM-GIC) and IZ (GIC), a fluoride-releasing composite, B II (giomer), a composite resin, Z250 and C (no treatment). According to the results of this study, the null hypothesis that the materials tested could not inhibit enamel demineralization in dynamic cycling-pH challenge was rejected.

The glass ionomer cements (F IX, IZ and F II) were chosen for evaluation in this study, as their anticariogenic potential effectiveness, been reported by several studies. (ASKAR et al., 2017)

The anticariogenic potential and the quantification of enamel elements $\mathrm{Ca} / \mathrm{P} / \mathrm{F}$ around restorative materials was estimated using in vitro models. Artificial enamel caries lesions are created to simulate the development of caries in vivo (VIEIRA et al., 2005). The production of enamel caries lesions models in vitro is able to simulate the dynamics of loss and gain of minerals, allowing a better understanding of the interaction between demineralization and remineralization processes. (WHITE, 1995; MAGALHÃES, 2009)

Caries is a multifactorial, biofilm-dependent sugar disease (CURY; TENUTA, 2009). Thus, biofilm accumulation is the mean factor and sugar exposure is the negative determinant for caries progression on any intact or restored dental surface. The $\mathrm{pH}$ is the driving force that regulates the loss or gain of $\mathrm{Ca}$ and $\mathrm{P}$ from the mineral structure of the teeth. (FEJERSKOV, 2004; CURY, 2016)

According to some studies, the enamel hardness is related to the mineral concentration in enamel, indicating a high correlation of the microhardness with microradiography analysis results, considered as a gold standard for the evaluation of mineral loss. (ARENDS et al., 1979; FEATHERSTONE et al., 1983; KIELBASSA et al., 1999; MAGALHÃES et al., 2009)

Surface hardness analysis results, in the present study, showed that glass ionomer cements (GICs and RM-GIC) were able to partially inhibit enamel demineralization at a greater extent. Among them, there was evidence that B II 
showed an intermediate behavior between F IX, IZ, F II, Z250 and C (no treatment), with a significantly higher hardness values than Z250 and C (no treatment).

The mechanism in which glass ionomer cements release fluoride ions into an oral environment is proposed by two processes. Process I is a short-term reaction involving a fast dissolution of fluoride in the medium. The process II is more gradual and results in a diffusion of fluoride through the cement (DHONDT et al., 2001; WILLIAMS et al., 2001, WIEGAND et al., 2007; DIONYSOPOULOS et al., 2013). In the present study, the release of F IX, IZ and F II (GICs and RM-GIC) was probably due to an initial "burst" of fluoride release from the glass particles, which occurred when the fluoride-containing glass powder reacted with polyalkanoic acid, so the enamel surface hardness averages were higher in comparison to B II and Z250.

Resin-modified glass ionomer cements (RM-GIC) were created to have a potential for fluoride release in amounts equivalent to conventional GICs. However, this potential is affected by several variables: the presence of fluoride compounds and their interaction with polyalkanoic acids, as well as the type and amount of resin used for the polymerization reaction. (TJANDRAWINATA et al., 2004; DESCHEPPER et al., 1991; DIONYSOPOULOS, 2013).

Among fluoride releasing materials, the distance of $150 \mu \mathrm{m}$ from the F II (RMGIC) showed the greatest hardness, but there was no statistical difference between GICs.

A possible explanation for these results is that when more distant the restorative material be, the surface hardness decreases, but $F$ IX, IZ and F II maintain a high hardness standard.

Giomers are presented in B II, a universal nanohybrid composite resin, composed by a surface pre - reacted glass (S-PRG) fillers. This S-PRG filler is formed by an acid/base reaction between glass particles (fluoride, boron, aluminum silicate filaments and polyalkanoic acid) in the presence of water, prior to being inserted into the resin and function as a filler in the resin matrix. Thus, Beautifil II differ from compomers, because the glass ionomer hydrogel inside compomers are formed after contact with water, that occur after polymerization (NAOUM et al., 2011). In addition to being an aesthetic material it is also indicated for restorations of cervical lesion, bonding of orthodontic brackets and patients who are at high risk for caries. The hardness results of B II and Z250 composite resins were statistically 
smaller compared to GICs and RM-GIC, and larger than C (no treatment). These results, could confirm hydroxyapatite dissolution and minerals loss in the medium in the absence of remineralizing agents.

The hardness loss demonstrated by $C$ (no treatment) was important for validation the $\mathrm{pH}$ cycling used in this study (VIEIRA et al., 2005), demonstrated that bovine enamel demineralization had occurred, providing the proposed cariogenic challenge.

Some research gathered evidence to show the importance of fluoride mechanism and its topical effect to delay the progression of the lesion (FEJERSKOV et al., 1981; FEJERSKOV, 2004). Fluoride works at the point of acid attack to inhibit demineralization and stimulate remineralization. It inhibits the progression of bacterial metabolism and the progression of caries (KIDD, 2011; BUZALAF et al., 2013).

Therefore, the inhibition of secondary caries associated with fluoride-releasing materials is attributed to a maintenance release of fluoride ions around restoration margins (Dijkman; Arends, 1992; Dionysopoulos et al., 2013; ASKAR et al. 2017).

Among the conditions of this study, the EDS analysis did have proved to be a sensitive and effective method to detect minor alterations of $\mathrm{Ca} / \mathrm{P} / \mathrm{F}$ mineral content as likewise occurred in the surface hardness evaluation.

However, the results of the EDS analysis after $\mathrm{pH}$ cycling showed that (GICs and RM-GIC) F IX, IZ and F II presented similar results, without statistical difference of calcium, phosphorus and fluoride ions percentages between the groups. This result was in agreement with previous findings (YAP et al., 2002; DIONYSOPOULOS et al., 2013).

In contrast, B II suffered a significant loss for calcium and a significant increase of fluoride in the enamel adjacent to the restoration. For Z250 and C (no treatment) there was no significant change in calcium, phosphorus and fluoride after $\mathrm{pH}$ cycling.

Based on our findings, the glass ionomer-based materials evaluated could release fluoride at a sufficient doses that partially inhibit the formation of new lesions during the $\mathrm{pH}$ cycle. 

4 FINAL

CONSIDERATIONS 



\section{FINAL CONSIDERATIONS}

Based on the findings of this in vitro study, the fluoride releasing restorative materials tested were able to partially inhibit enamel demineralization when subjected to a dynamic $\mathrm{pH}$ cycling model, with the best behavior of the glass ionomer cement, followed by giomer. The composite resin did not present an anticariogenic potential and the quantifying enamel mineral elements around restorative materials, the giomer Beautifil II presented calcium ions loss and a greater incorporation of fluoride ions in enamel. However, considering the limitations of this study, further long-term analysis and in vivo studies are required to determine the efficacy of these materials in the control of caries lesions. 




\section{REFERENCES}

Arends J, Schuthof J, Jongebloed WG. Microhardness indentations on artificial white spot lesions. Caries Research, v.13, v.5, p.290-297, 1979.

Askar H, Tu YK, Paris S, Yeh YC, Schwendicke F. Risk of caries adjacent to different restoration materials: Systematic review of in situ studies. Journal of Dentistry, v.56, p.1-10, 2017.

Behnan SM, Arruda AO, González-Cabezas, C, Sohn, W. In-vitro evaluation of various treatments to prevent demineralization next to orthodontic brackets. American Journal Orthodontics Dentofacial Orthophedic, v.13, n.8, p.712-721, 2010.

Costa SM, Martins CC, Bonfim Mde L, Zina LG, Paiva SM, Pordeus IA, Abreu MH. A systematic review of socioeconomic indicators and dental caries in adults. International Journal Environ Research Public Health, v.9, n.10, p.3540-3574, 2012.

Cury JA, de Oliveira BH, Dos Santos AP, Tenuta LM. Are fluoride releasing dental materials clinically effective on caries control? Dental Materials Journal, v.32, n.3, p.323-333, 2016.

Cury JA, Tenuta LMA. Enamel remineralization: controlling the caries disease or treating early caries lesions? Brazilian Oral Research, v.23, n.1, p.23-30, 2009.

DeSchepper EJ, Berr EA, Cailletean JG, Tate WH. A comparative study of fluoride release from glass ionomer cements. Quintessence International, v.22, n.3, p.215219, 1991.

Dijkman GE, Arends J. Secondary caries in situ around fluoride-releasing light-curing composites: a quantitative model investigation on four materials with fluoride content between 0 and 26 vol\%. Caries Research, v.26, n.5. p.351-357, 1992.

Dionysopoulos P, Koliniotou-Koumpia E, Helvatzoglou-Antoniades M, Kotsanos N. Fluoride release and recharge abilities of contemporary fluoride-containing restorative materials and dental adhesives. Dental Materials Journal, v. 32, n.2, p. 296-304, 2013. 
Dhondt CL, De Maeyer EA, Verbeeck RM. Fluoride release from glass ionomer activated with fluoride solutions. Journal Dentistry Research, v.80, n.5, p.14021406, 2001.

Featherstone JDB, ten Cate JM, Shariati M, Arends J. Comparison of artificial carieslike lesions by quantitative microradiography and microhardness profiles. Caries Research, v.17, n.5, p.385-391, 1983.

Fejerskov O. Changing paradigms in concepts on dental caries: consequences for oral health care. Caries Research, v.38, n.3, p.182-191, 2004.

Fejerskov O, Thylstrup A, Larson MJ. Rational use of fluorides in caries prevention. A concept based on possible cariostatic mechanisms. Acta Odontologica Scandinavica, v.39, n.4, p.241-249, 1981.

Ferracane, J.L. Resin composite - state of the art. Dental Materials Journal, v.27, n.1, p.29-38, 2011.

Forsten, L. Resin-modified glass ionomer cements: fluoride release and uptake. Acta Odontologica Scandinavica, v.53, n.4, p.225-235, 1995.

Garcia-Contreras R, Scougall-Vilchis RJ, Contreras-Bulnes R, Sakagami H, MoralesLuckie RA, Nakajima H. Mechanical, antibacterial and bond strength properties of nano-titanium enrinched glass ionomer cement Journal of Applied Oral Science, v.2, n.3, p.321-328, 2015.

Hotwani K, Thosar K, Baliga S, Bundale S, Sharma K. Antibacterial effects of hybrid tooth colored restorative materials against Streptococcus mutans: An in vitro analysis. Journal of Conservative Dentistry, v.16, n.4, p.319-322, 2013.

Kidd E. The implications of the new paradigm of dental caries. Journal of Dentistry, v.39, n. 2, p.3-8, 2011.

Kielbassa AM, Wrbas KT, Schulte-Mönting J, Hellwig E. Correlation of transversal microradiography and microhardness on in situ-induced demineralization in irradiated and nonirradiated human dental enamel. Archives of Oral Biology, v.44, n.3, p.243251, 1999.

Lippert F, Churchley D, Lynch R.J. Effect of Lesion Baseline Severity and Mineral Distribution on Remineralization and Progression of Human and Bovine Dentin Caries Lesions. Clinical Oral Investigation, v.19, n.8, p.1947-1954, 2015. 
Magalhães AC, Moron BM, Comar LP, Wiegand A, Buchalla W, Buzalaf MA. Comparison of cross-sectional hardness and transverse microradiography of artificial carious enamel lesions induced by different demineralising solutions and gels. Caries Research, v.43, n.6, p.474-483, 2009.

Marcenes W, Kassebaum NJ, Bernabé E, Flaxman A, Naghavi M, Lopez A, Murray CJ. Global burden of oral conditions in 1990-2010: a systematic analysis. Journal Dentistry Research, v.92, n.7, p.592-597, 2013.

Naoum S, Ellakwa A, Martin F, Swain M. Fluoride Release, Recharge and Mechanical Property Stability of Various Fluoride - Containing Resin Composite. Operative Dentistry, v.36, n.4, p.422-432, 2011.

Steckse n-Blicks C, Renfors G, Oscarson ND, Bergstrand F, Twetman S. Cariespreventive effectiveness of a fluoride varnish: a randomized con- trolled trial in adolescents with fixed orthodontic appliances. Caries Research, v.41, n.6, p. 455459, 2007.

ten Cate JM, Featherstone JD. Mechanistic aspects of the interactions between fluoride and dental enamel. Crit Rev Oral Biol Med, v.2, n.3, p.283-296, 1991.

Tjandrawinata R, Irie M, Suzuki K. Marginal gap formation and fluoride release of resin-modified glass-ionomer cement: effect of silanized spherical silica filler addition.

Dental Materials Journal, v.23,n.3, p.305-313, 2004.

Vieira AE, Delbem AC, Sassaki KT, Rodrigues E, Cury JA, Cunha RF. Fluoride dose response in $\mathrm{pH}$-cycling models using bovine enamel. Caries Research, v.39, n.6, p.514-520, 2005.

Wiegand A, Buchalla W, Attin T. Review on fluoride-releasing restorative materials Fluoride release and uptake characteristics, antibacterial activity and influence on caries formation. Dental Materials Journal, v.23, n.3, p.343-362, 2007.

Williams JA, Billington RW, Pearson GJ. A long-term study of fluoride release from metal-containing conventional and resin-modified glass-ionomer cements. Journal Oral Rehability, v.28, n.1, p. 41-47, 2001.

White DJ. The application of in vitro models to research on demineralization and remineralization of the teeth. Adv Dent Research, v.9, n.3, p.175-193, 1995.

Yap AU, Tham SY, Zhu LY, Lee HK. Short-term fluoride release from various aesthetic restorative materials. Operative Dentistry, v.27, n.3, p.259-265, 2002. 
Zero DT. Dental caries process. Dental Clin North American, v.43, n.4, p.635-664, 1999. 
ANNEXES 



\section{ANNEX A - Guidelines for Operative Dentistry submissions:}

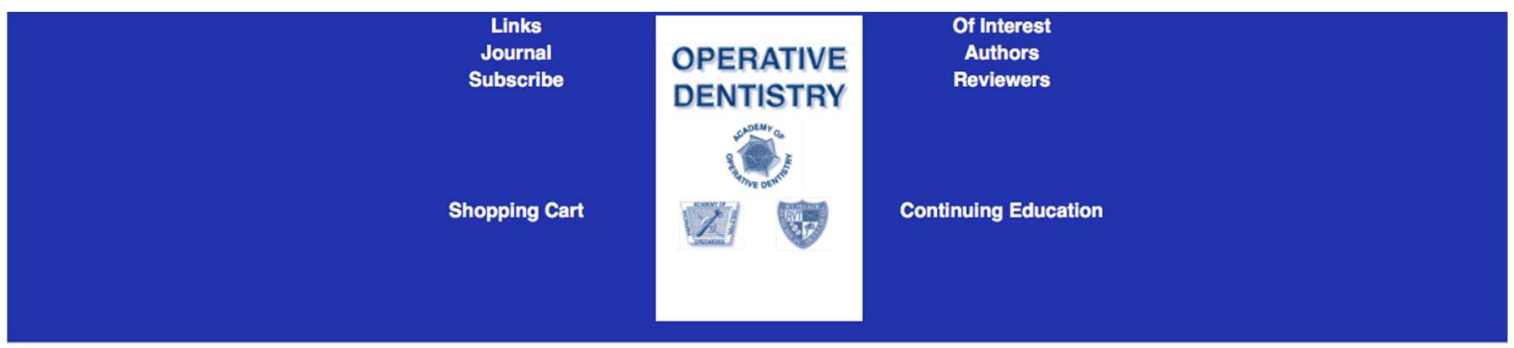

\section{INSTRUCTIONS TO AUTHORS}

\section{New Instructions as of 20 September 2008} Operative Dentistry requires electronic submission of all manuscripts. All submissions must be sent to Operative Dentistry using the Allen Track upload site. Your manuscript will only be
considered officially submitted after it has been approved through our initial quality control check, and any problems have been fixed. You will have 6 days from when you start the process to submit and approve the manuscript. After the 6 day limit, if you have not finished the submission, your submission will be removed from the server. You are still able to submit the manuscript, but you must start from the beginning. Be prepared to submit the following manuscript files in your upload:

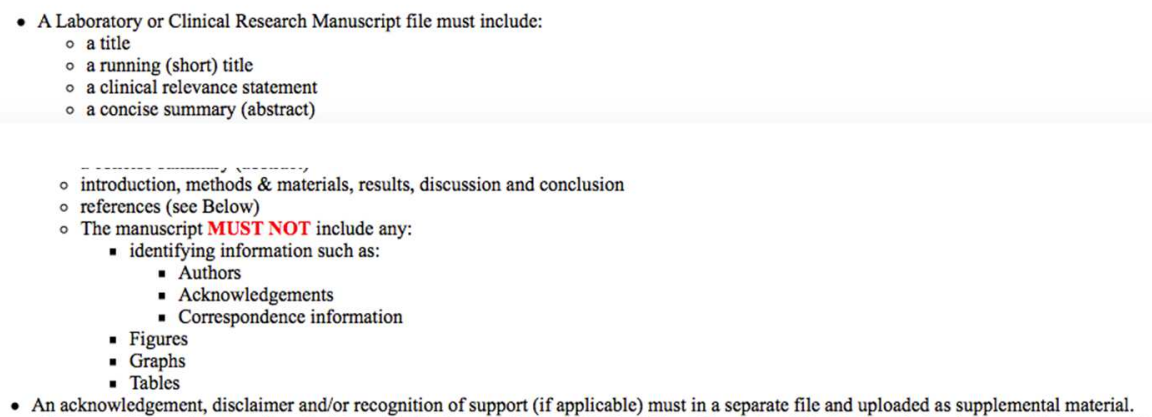

- An acknowledgement, disclaimer and/or recognition of support (if applicable) must in a separate file and uploaded as supplemental material.

- All figures, illustrations, graphs and tables must also be provided as individual files. These should be high resolution images, which are used by the editor in the actual typesetting of your manuscript. Please refer to the instructions below for acceptable formats.

- All other manuscript types use this template, with the appropriate changes as listed below.

Complete the online form which includes complete author information and select the files you would like to send to Operative Dentistry. Manuscripts that do not meet our formatting and data requirements listed below will be sent back to the corresponding author for correction.

\section{GENERAL INFORMATION}

- All materials submitted for publication must be submitted exclusively to Operative Dentistry.

- The editor reserves the right to make literary corrections.

- Currently, color will be provided at no cost to the author if the editor deems it essential to the manuscript. However, we reserve the right to convert to gray scale if color does not

contribute significantly to the quality and/or information content of the paper.

- The author(s) retain(s) the right to formally withdraw the paper from consideration and/or publication if they disagree with editorial decisions.

- International authors whose native language is not English must have their work reviewed by a native English speaker prior to submission.

- Spelling must conform to the American Heritage Dictionary of the English Language, and SI units for scientific measurement are preferred.

- While we do not currently have limitations on the length of manuscripts, we expect papers to be concise; Authors are also encouraged to be selective in their use of figures and tables,

using only those that contribute significantly to the understanding of the research.

- Acknowledgement of receipt is sent automatically. If you do not receive such an acknowledgement, please contact us at editor@jopdent.org rather than resending your paper.

- IMPORTANT: Please add our e-mail address to your address book on your server to prevent transmission problems from spam and other filters. Also make sure that your server will

accept larger file sizes. This is particularly important since we send page-proofs for review and correction as .pdf files. 


\section{REQUIREMENTS}

\section{- FOR ALL MANUSCRIPTS}

1. CORRESPONDING AUTHOR must provide a WORKING / VALID e-mail address which will be used for all communication with the journal.

NOTE: Corresponding authors MUST update their profile if their e-mail or postal address changes. If we cannot contact authors within seven days, their manuscript will be removed from our publication queue.

2. AUTHOR INFORMATION must include:

- full name of all authors

- complete mailing address for each author

- degrees (e.g. DDS, DMD, PhD)

- affiliation (e.g. Department of Dental Materials, School of Dentistry, University of Michigan)

3. MENTION OF COMMERCIAL PRODUCTS/EQUIPMENT must include:

- full name of product

name of manufacturer

- city, statc and/or country of manufacturer

4. MANUSCRIPTS AND TABLES must be provided as Word files. Please limit size of tables to no more than one US letter sized page. ( $81 / 2$ " $\left.\times 11^{\prime \prime}\right)$

5. ILLUSTRATIONS, GRAPHS AND FIGURES must be provided as TIFF or JPEG files with the following parameters

- line art (and tables that are submitted as a graphic) must be sized at approximately 5 " $\mathrm{x} 7$ " and have a resolution of $1200 \mathrm{dpi}$.

- gray scale/black \& white figures must have a minimum size of 3.5 " x 5", and a maximum size of 5 " x 7" and a minimum resolution of 300 dpi and a maximum of $400 \mathrm{dpi}$.

- color figures must have a minimum size of 2.5 " $\times 3.5$ ", and a maximum size of 3.5 " x 5 " and a minimum resolution of $300 \mathrm{dpi}$ and a maximum of $400 \mathrm{dpi}$.

- color photographs must be sized at approximately 3.5 " $\times 5$ " and have a resolution of $300 \mathrm{dpi}$.

\section{- OTHER MANUSCRIPT TYPES}

1. CLINICAL TECHNIQUE/CASE STUDY MANUSCRIPTS must include:

- a running (short) title

- purpose

- description of technique

- list of materials used

- list of materials used

- potential problems

- summary of advantages and disadvantages

- summary of advantages

2. LITERATURE AND BOOK REVIEW MANUSCRIPTS must include:

- a running (short) title

- a clinical relevance statement based on the conclusions of the review

- conclusions based on the literature review....without this, the review is just an exercise

- references (see below)

\section{- FOR REFERENCES}

REFERENCES must be numbered (superscripted numbers) consecutively as they appear in the text and, where applicable, they should appear after punctuation.

The reference list should be arranged in numeric sequence at the end of the manuscript and should include:

1. Author(s) last name(s) and initial (ALL AUTHORS must be listed) followed by the date of publication in parentheses.

2. Full article title.

Full journal name in italics (no abbreviations), volume and issue numbers and first and last page numbers complete (i.e. 163-168 NOT attenuated 163-68).

Abstracts should be avoided when possible but, if used, must include the above plus the abstract number and page number.

Book chapters must include chapter title, book title in italics, editors' names (if appropriate), name of publisher and publishing address.

6. Websites may be used as references, but must include the date (day, month and year) accessed for the information.

. Papers in the course of publication should only be entered in the references if they have been accepted for publication by a journal and then given in the standard manner with "In press" following the journal name.

8. DO NOT include unpublished data or personal communications in the reference list. Cite such references parenthetically in the text and include a date.

\section{EXAMPLES OF REFERENCE STYLE}

- Journal article: two authors

Evans DB \& Neme AM (1999) Shear bond strength of composite resin and amalgam adhesive systems to dentin American Journal of Dentistry 12(1) 19-25.

- Journal article: multiple authors

Eick JD, Gwinnett AJ, Pashley DH \& Robinson SJ (1997) Current concepts on adhesion to dentin Critical Review of Oral and Biological Medicine 8(3) 306-335.

Journal article: two authors

Evans DB \& Neme AM (1999) Shear bond strength of composite resin and amalgam adhesive systems to dentin American Journal of Dentistry 12(1) 19-25.

- Journal article: multiple authors

Eick JD, Gwinnett AJ, Pashley DH \& Robinson SJ (1997) Current concepts on adhesion to dentin Critical Review of Oral and Biological Medicine 8(3) 306-335.

- Journal article: special issue/supplement

Van Meerbeek B, Vargas M, Inoue S, Yoshida Y, Peumans M, Lambrechts P \& Vanherle G (2001) Adhesives and cements to promote preservation dentistry Operative Dentistry (Supplement 6) 119-144.

- Abstract:

Yoshida Y, Van Meerbeek B, Okazaki M, Shintani H \& Suzuki K (2003) Comparative study on adhesive performance of functional monomers Journal of Dental Research 82(Special Issue B) Abstract \#0051 p B-19.

- Corporate publication:

ISO-Standards (1997) ISO 4287 Geometrical Product Specifications Surface texture: Profile method - Terms, definitions and surface texture parameters Geneve: International Organization for Standardization 1 st edition 1-25.

- Book: single author

Mount GJ (1990) An Atlas of Glass-ionomer Cements Martin Duntz Ltd, London.

- Book: two authors

Nakabayashi N \& Pashley DH (1998) Hybridization of Dental Hard Tissues Quintessence Publishing, Tokyo.

- Book: chapter

Hilton TJ (1996) Direct posterior composite restorations In: Schwarts RS, Summitt JB, Robbins JW (eds) Fundamentals of Operative Dentistry Quintessence, Chicago 207-228.

- Website: single author

Carlson L (2003) Web site evolution; Retrieved online July 23, 2003 from: http://www.d.umn.edu/ lcarlson/cms/evolution.html

- Website: corporate publication

National Association of Social Workers (2000) NASW Practice research survey 2000. NASW Practice Research Network, 1. 3. Retrieved online September 8, 2003 from: http://www.socialworkers.org/naswprn/default 